\title{
Tarihsel Yığma Yapıların Hâlihazır Koruma Durumunun İzlenmesi İçin Öneriler: Matrone Kilisesi ve Çardak Han Örneği
}

\author{
Proposals for Monitoring Current Conservation Condition of Historical Masonry \\ Buildings: Matrone Church and Çardak Han Cases
}

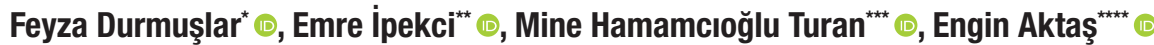

Öz

Bu yazının amacı, tarihsel yığma yapıların tespit ve izlenme süreciyle ilgili uluslararası gelişmelerin ulusal alana aktarılmasıdır. Seçilen yöntem, uluslararası düzeyde yapılan önerilerin ulusal vakalar üzerinde sınanması, elde edilen sonuçların karşılaştırılarak tartışılması şeklindedir. Hâlihazır analitik belgeleme sürecinde yer alan; ön çalışmalara ulaşma, yapıyı yerinde gözlemleme, ölçülü belgeleme, malzeme karakterizasyonu, haritalama ile görsel analiz aşamaları sürdürülmüştür. Ancak yapısal özellikler ve sorunların da incelenmesi vurgulanmaktadır. İlgili riskler; 2012 tarihli, UNI EN 16096 numaralı, Kültür Varlıklarının Korunması - Mimari Mirasın Durum Tespiti ve Raporlanması başlıklı standartta tanımlanan durum sınıfları dikkate alınarak değerlendirilmekte ve koruma durumuna göre müdahale öncelikleri belirlenmektedir. Ege bölgesinden, farklı hasar tip ve dağılımı içeren, farklı dönemlere ait iki tarihi yığma yapı seçilmiştir. İzmir, Çeşme, Ildırı'daki Matrone Kilisesi ve Denizli'deki Çardak Hanı'nın koruma durumu raporları hazırlanmıştır. Bu örneklemelerin sonucunda, tarihsel yığma yapıların hâlihazır koruma durumunun izlenmesinde dikkat edilmesi gerekenler belirlenmiştir. Özgün yapım özelliklerinin ve ilgili hasarların doğru kavranmasının kültür varlığı olan tarihsel yığma yapıların sürdürülmesinde önceliği vardır. Her tarihsel yığma yapı bütünü için genel bir koruma durumu sınıfı tanımlanması ve risk değerlendirmesi, Avrupa standartlarını ve mimari restorasyon alanındaki güncel gelişimleri dikkate alan ancak ülkemiz örneklerine özgü olarak geliştirilecek bir standart çerçevesinde yapılmalıdır. Böylece kültür varlıklarımızın birbirleriyle kıyaslamalı olarak hasar durumlarının değerlendirilmesi mümkün olacaktır. Müdahaleler, doğru sırada ve kapsamda, gerekli disiplinlerin katılımı ile planlanabilecektir.

Anahtar Kelimeler

Durum Raporu, Avrupa Standardı, Tarihi Yığma Yapılar, Koruma

\section{Abstract}

The aim of this study is to transfer the international developments related to the process of diagnosis and monitoring of historical masonry structures to the national area. The method chosen is to test the recommendations made at

* Sorumlu Yazar: Feyza Durmuşlar (Arş. Gör.), Yaşar Üniversitesi, Mimarlık Fakültesi, Mimarlık Bölümü, İzmir, Türkiye. E-posta: feyza.durmuslar@yasar.edu.tr ORCID: 0000-0003-3528-4835

** Emre İpekci (Arş. Gör.), İzmir Yüksek Teknoloji Enstitüsü, Mimarlık Fakültesi, Mimari Restorasyon Bölümü, İzmir, Türkiye. E-posta: emreipekci@iyte.edu.tr ORCID: 0000-0003-2433-1341

*** Mine Hamamcıoğlu Turan (Prof. Dr.), İzmir Yüksek Teknoloji Enstitüsü, Mimarlık Fakültesi, Mimari Restorasyon Bölümü, İzmir Türkiye. E-posta: mineturan@iyte.edu.tr ORCID: 0000-0002-7418-9577

**** Engin Aktaş (Doç. Dr.), İzmir Yüksek Teknoloji Enstitüsü, Mühendislik Fakültesi, İnşaat Mühendisliği Bölümü, İzmir, Türkiye. E-posta: enginaktas@iyte.edu.tr. ORCID: 0000-0002-5706-2101

Atıf: Durmuslar, Feyza, Ipekci, Emre, Hamamcioglu-Turan, Mine ve Aktas, Engin. "Tarihsel Yığma Yapıların Hâlihazır Koruma Durumunun İzlenmesi İçin Öneriler: Matrone Kilisesi ve Çardak Han Örneği.” Art-Sanat, 14(2020): 111-133. https://doi.org/10.26650/artsanat.2020.14.0005 
the international level on national cases and to discuss the results obtained by comparing them. A review of preliminary studies, on-site observations, measured surveys, material characterizations, mapping and visual analysis have been carried out. An examination of structural characteristics and observed failures have also been detailed. Related risks have been evaluated with criteria developed by taking into consideration condition classes defined in the UNI EN 16096, titled Conservation of Cultural Property - Condition Survey and Report of Built Cultural Heritage. According to the defined risks and classes, priorities of interventions were determined. Two historical masonry buildings which possess characteristics of different periods and present different damage types were selected: Matrone Church in IIdırı, Çeşme, İzmir and Çardak Han in Çardak, Denizli. The condition reports of the selected buildings have been prepared. The critical points in the condition reporting of historical masonry buildings were determined: accurate comprehension of the authentic structural characteristics and related failures have priority in maintaining historical masonry structures. Identification of condition class and risk assessment of each historic masonry building should be made in accordance with a standard specific to the cases of our country, but in line with the European standards and current developments in the field of architectural restoration. Thus, it will be possible to evaluate the conservation state of our masonry assets in comparison with each other. The content and priority of interventions can be well planned with the participation of the necessary disciplines.

\section{Keywords}

Condition Report, European Standard, Historical Masonry Structures, Conservation

\section{Extended Summary}

In order to document and conserve immovable cultural assets in Turkey, inventory sheets have been used. These inventory sheets include written and visual information for definition of cultural assets. However, there is a lack of information in terms of risks and intervention decisions. It might not be enough using only listed cultural assets by inventories but also, they should be monitored according to their conditions. In addition, each phase of intervention should be defined and planned. A condition survey is a management tool for developing plans and consideration for further measures. In order to provide unity in efforts to monitor the conservation condition, a European Standardization Committee produced a standard, UNI EN 16096 titled "Conservation of cultural property-Condition survey and report of built cultural heritage". It provides guidelines for a condition survey of built cultural heritage by stating assessment, documentation, recording and reporting methods. This European Standard, identifies maintenance measures and defines procurement needs for a group of buildings or a region. According to this standard, the statuses of the buildings can mostly be evaluated by visual observation, and simple measurements can be made if necessary. Relevant data and documents should also be collected and added to the status report. First, general information about built cultural heritage should be recorded - such as a description in the form of a short text of the condition, the symptoms, the type and extent of any damage and condition of the components. Defined symptoms of the structure are analyzed and divided into classes according to the physical state of a built cultural heritage. Condition class 0 refers to no symptoms whereas condition class 3 exhibit major symptoms. There are other classes - minor and moderately strong symptoms. Minor symptoms are few broken elements or worn paint, whereas moderately strong symptoms are localized damage caused by minor wet rot infestation 
and partial replacement. Major symptoms are leaking roof with damage and major damages. According to condition classes, risk assessments are carried out and their urgency is defined. Risk assessments include probable causes for recorded conditions, external actions affecting components, expected variations in external actions and probable consequences due to recorded conditions, probability that may cause further deterioration, requirements for further investigations and its effect on hidden damage, effect on historical significance and urgency of measures. Urgency class 0 refers to long term interventions, again urgency class 3 require urgent and immediate actions. Depending on the risk assessment, recommended measures for all components are defined in four different classes ranging from recommendation class 0 (no measures) to recommendation class 3 (major intervention based on diagnosis). Maintenance, preventive measures and simple repair can be recommended. Maintenance is defined as periodic preventive conservation actions aimed at sustaining the appropriate condition of the heritage. Preventive conservations are measures and actions taken in order to avoid and minimize future damage, deterioration and loss. Repair refers to actions that recover an object's functionality and its appearance. These types of interventions are not only to conserve and maintain the significance of built cultural heritages but also to retain their authenticity and integrity. A condition report defines the process necessary for sustaining built cultural heritages in a stable and maintained condition. In its scope and terminology, it is suitable for historical buildings, especially for masonry. Determination of current conditions of historic masonry structures is a significant step for conservation studies. Even though the usage of this method is common for other stakeholders of this committee, it is still not applied to the process in Turkey. In addition, there is a lack of monitoring and continuous maintenance of cultural assets. After restoration, they are not monitored and maintained. The purpose of this paper is to transmit the international advancements identified with the procedure of documenting, analyzing and monitoring of cultural assets to the national area. This developed strategy furnishes an assessment method of historical components in different conditions and provides planning in a defined schedule. The selected method is to test the proposals made at the global level on national cases and discourse about the outcomes with comparisons. For this reason, the European Standard was used to determine condition reports of two masonry buildings: Matrone Church, Ildir1, İzmir and Çardak Khan, Çardak, Denizli. Matrone Church was built in the $19^{\text {th }}$ century. However, it was abandoned in the early $20^{\text {th }}$ century with the population exchange. It was demolished in 1948 and therefore, it was in ruins. With the excavations of Erythrai, the monument was listed as a part of a 1st degree archaeological site. Çardak Khan was built in the 13 th century. It was used until the early 20 th century with different functions and later abandoned in the 1960s. The building was listed in 1991. Due to vandalism, the walls of the Khan were damaged. The church ruin and abandoned khan were belonging to Turkish periods. Both monuments were compensated due to aban- 
donment and anthropogenic reasons. Within this frame, architectural, structural and material properties of the historic buildings were defined. Structural failures and material deterioration were identified and categorized into three condition classes. Risk assessments including their urgency classes were performed and possible measures were proposed. The condition reports regarding the conservation state of historic masonry monuments prepared in the scope of this standard ease communication among different institutions of conservation and assure sustainability. 


\section{Giriş}

Türkiye' de taşınmaz kültür varlıklarının tespit işlemleri ${ }^{1}$ sırasında yapı ile ilgili yazılı ve görsel bilgileri içeren envanter fişleri hazırlanmaktadır. Bu fişlerde daha çok betimleyici bilgiler yer almakta, risk değerlendirmesi ve müdahale kararlarına dair bilgiler genellikle bulunmamaktadır. Ancak kültür varlığı yapıların tespit edilmesi ve tescillenmesi kadar, koruma durumlarının belirli aralıklarla izlenmesi ve müdahale sürecindeki aşamaların genel hatlarıyla ortaya konulduğu bir planlamanın yapılması önem taşımaktadır². Koruma durumunun izlenmesi çalışmalarında dil birliği sağlamak amaciyla, Avrupa Standardizasyon Komitesi ${ }^{3}$ tarafından 2012 yılında bir standart üretilmiştir. Bu standart ${ }^{4}$ koruma uzmanının alanda ve arşivde koruma durumu bilgisini hızlı ve sistemli olarak derlemesini kolaylaştırır niteliktedir. Ancak kapsam ve terminolojisi tek yapı ölçeği için, özellikle de yığma yapılar için uygundur. Örneğin tarihsel ahşap yapıların analitik belgelenmesiyle ilgili çalışmalarda ${ }^{5}$ ahşap türü, yapı elemanının formu, bağlantı tipi gibi özelliklere vurgu yapılırken; söz konusu standartta belirtilenler ayrıntılandırılmamıştır. Standart; risk değerlendirmesi ve acil müdahale önerileriyle ilgili olarak uzman görüşünün ortaya konmasına firsat tanımaktadır. Standart kapsamında tanımlanan süreç ve kavramlar şöyle özetlenebilir: Belgeleme işinin planlanması, yasal durum bilgisine ulaşılması, öncü çalışmalarda yer alan görsel ve yazılı bilginin derlenmesi, mevcut durumun gözlenerek betimlenmesi, gereği hâlinde basit ölçümler yapılması; her bir yapı elemanı için hâlihazır koruma durumunun incelenmesi ve koruma durumu sinıflandirmasinın yapılması ${ }^{6}$; hasar ve bozulmaların olası nedenlerinin ortaya konularak belgelenen durumun olası nedenleri, dış faktörleri, olası değişken ve sonuçları içeren bir risk değerlendirmesi yapılması ${ }^{7}$ ve acil müdahale gerekliliklerinin saptanmas1 $^{8}$. Diğer yandan; bu çerçeve içinde hazırlanan koruma durumu raporu, çok

12863 sayılı kanuna bağglı "Korunması Gerekli Taşınmaz Kültür Varlıklarının ve Sitlerin Tespit ve Tescili Hakkında Yönetmelik” Mart 2012’de Resmî Gazetede yayımlanmıştır.

2 Nihal Arığlu ve Seden Acun, "A Research about a Method for Restoration of Traditional Lime Mortars and Plasters: A Staging SystemApproach,” Building and Environment $41 / 9$ (2006), 1223-1230.

3 Comité Européen de Normalisation (CEN), 34 Avrupa ülkesinin Ulusal Standardizasyon Kuruluşlarını bir araya getiren uluslararası bir standardizasyon kuruluşudur.

4 Bu standardın tam adı "UNI EN 16096 (2012) (English): Conservation of cultural property- Condition survey and report of built cultural heritage" şeklindedir ve Haziran 2012'de onaylanmıştır. Avrupa Birliğine üye ülkeler, İzlanda, Norveç, İsviçre, Makedonya, Türkiye ve Sırbistan Avrupa Standardizasyon Komitesi’ne üyedir. Avrupa Standardizasyon Komitesi'nin misyonu; ticaret, endüstri, servis hizmetleri, kamu hizmetleri, araştırma, tüketim gibi alanlarda ihtiyaç duyulan standartların; kalite, güvenlik, iş birliği, erişilebilirlik, sürdürülebilirlik gibi ölçütleri dikkate alarak; şeffaf ve kâr amacı gütmeyen bir süreçte üretilmesi ve geliştirilmesidir. Komite üyeleri olan devletler üretilen standartlara uymakla yükümlüdürler.

5 Mariapaola Riggio vd., "Assesment of Heritage Timber Structures: Review of Standards, Guidelines and Procedures," Journal of Cultural Heritage 31 (2018), 220.

6 Sinıflandırma şu şekildedir: Koruma durumu 0 - sorun bulgusu yok, koruma durumu 1 -az sorun bulgusu, koruma durumu 2 - orta derecede sorun bulgusu ve koruma durumu 3 - çok sorun bulgusu.

7 Risk grupları: Uzun dönemde ele alınacaklar- aciliyet durumu 0, orta dönemde ele alınacaklar- aciliyet durumu 1, kısa dönemde ele alınacaklar- aciliyet durumu 2 ve öncelikle ele alınacaklar- aciliyet durumu 3 şeklinde önerilmektedir.

8 Müdahaleler grupları: İzleme - öneri sınıfı 0, bakım ve önleyici koruma - öneri sınıfı 1, basit onarım ve incelemenin ayrıntılandırılması - öneri sınıfı 2 ve teşhise dayalı kapsamlı müdahale - öneri sınıfı 3 şeklindedir. 
küçük yapı elemanlarının (örnek: bir tonozun üzerindeki sıva kalıntısı) dahi tek tek ele alındığı çok uzun bir belgeye dönüşmektedir. Bu parçacı yaklaşım, ayrıntıların yakalanmasına firsat vermekte ancak yapı bütününün kavranmasını güçleştirmektedir. Koruma uzmanının aşina olduğu analitik çizimleri kapsamı içinde zaruri görmemesi de koruma değer ve sorunlarının anlaşılmasını güçleştiren diğer bir nedendir.

Standardardizasyon çalışmalarının yanısıra; tarihsel yığma yapıların koruma durumunun saptanması ve izlenmesi, güncel bir araştırma alanı olmaya devam etmektedir. Tarihsel yığma yapıların analitik belgelenmesi için yeni bir yöntem öneren Antoni Borri ve ekibinin çalışmasında yedi parametrenin analizi önerilmektedir ${ }^{9}$. Her bir parametre gereksinimlere uygunluk durumuna göre (uygun, kısmen uygun, uygun olmayan) sinıflandırılmakta ve sayısal bir değer kazanmaktadır. Her parametrenin değerlendirilmesiyle toplamda elde edilen değer, taş duvarın kalitesini (yığma yapı kalite indeksi) belirlemekte ve olası üç sonuca (iyi, orta, yetersiz) ulaşılmaktadır. Dolayısı ile özgün tasarımdan kaynaklanan koruma sorunlarının ya da nitelikli tasarım tercihlerinin tespiti de yapılabilmektedir. Sonuçta, tarihi yığma yapının; malzeme, ölçü, şekil, derz detayları gibi yapım özelliklerinin yer aldığı bir katalog hazırlanmıştır. Xavier Romão ve ekibinin çalışmasında ise, kültür varlıklarının ön değerlendirme aşaması için basitleştirilmiş bir risk değerlendirme analizi yapılmıştır ${ }^{10}$. Bu analiz sonucunda; sayısal tahminler sunmak yerine, karşılaşılabilecek tehditlerin betimlendiği beş risk kategorisi belirlenmiştir: 1 . ve 2. seviye kabul edilebilir risk grubu, 3. seviye sürekli gözlemlenmesi gereken grup, 4. ve 5. seviyeler acil müdahale gerektiren, kabul edilemez risk grubu. Sonuç olarak, olası üç hasar seviyesi (hafif, orta, ağır) tanımlanmıştır. Orta ve ağır hasar seviyeleri için de onarım analizi yapılmalı ve güçlendirme ihtiyacı sorgulanmalıdır. Bu yaklaşım uzmana hızlı bir ön değerlendirme yapma firsatı sunmaktadır. Masciotta ve ekibi (2019) önleyici koruma uygulamalarını yönlendirmek üzere, mimari mirasın koruma durumu raporlaması için bir yöntem önermiştir. Yukarıda belirtilen Avrupa standardından yola çıkan çalışma, yapı elemanlarından başlanarak yapı bütünü için nasıl bir koruma durumu değerlendirmesi yapılabileceğine dair ipuçları ortaya koymuştur. Tarihi yapılarda karşılaşılabilecek hasar ve bozulma tipleri tanımlanmış, önem sırasına göre sınıflandırılmıştır. Bu hasarların varlığı ve yoğunluğu dikkate alınarak, dört farklı koruma durumu belirlenmiş, öncelikle her bir yapı elemanının hangi gruba dahil olduğunun değerlendirilmesi önerilmiştir. Yapıdaki belirli bir bölgenin koruma durumunu tanımlamak için ise, o bölgedeki yapı elemanları içinde en kötü koruma durumu puanı alan, bölge puanı olarak tanımlanmıştır. Yapı bütününün koruma durumunun belirlenmesinde ise tüm bölgelerin puanlarının ağırlıklı ortalaması alınmıştır. Farklı fiziksel özellikleri ve hasar

9 Yedi parametre şunlardır: Malzemenin dayanımı, taş/ tuğla ölçüleri, taş/tuğla şekli, farklı katmanların birleşme detayı, yatay derz karakteristiği, dikey derz karakteristiği ve mekanik harç özellikleri. Antoni Borri vd., "A Method for the Analysis and Classification of Historic Masonry," Bullettin of Earthquake Engineering, 13 (2015), 2647.

10 Xavier Romão vd., "A Framework for the Simplified Risk Analysis of Cultural Heritage Assets," Journal of Cultural Heritage 20 (2016), 696. 
durumları bulunan vakaların, benzer terimler ve ölçütler kullanılarak koruma durumları ortaya konmuş; sonuçlar karşılaştırılmıştır ${ }^{11}$.

Bu yazının amacı, tarihsel yığma yapıların tespit ve izlenmesi süreciyle ilgili uluslararası gelişimlerin ulusal alana aktarılmasıdır. Seçilen yöntem, uluslararası düzeyde yapılan ve yukarıda özetlenen önerilerin ulusal vakalar üzerinde sınanması, elde edilen sonuçların karşılaştırılarak tartışılması şeklindedir. Ege bölgesinden, farklı hasar tip ve dağılımı içeren farklı dönemlere ait iki tarihi yı̆̆ma yapı seçilmiş ve uluslararası çalışmalarda ortaya konan yaklaşımlar sınanmıştır. İzmir, Çeşme, Ildırı' daki Matrone Kilisesi $^{12}$ ve Denizli'deki Çardak Hanı'nın koruma durumu raporları hazırlanmıştır. Hâlihazır analitik belgeleme sürecinde yer alan; ön çalışmalara ulaşma, yapıyı yerinde gözlemleme, ölçülü belgeleme, malzeme karakterizasyonu, haritalama ile görsel analiz aşamaları sürdürülmüştür. Ancak yapısal nitelik ve sorunların incelenmesi de vurgulanmaktadir. Koruma durumu sinıflandırması yapılırken, her bir yap1 elemanının strüktürel hasar ve malzeme bozulmaları dikkate alınmış ancak bu elemanların birbirleriyle ilişkileri de gözetilerek, sorunların önem ve dağılımına göre birbirinden farklılaşan hasar ve bozulma bölgeleri belirlenmiştir (T. 1).

\section{Tablo 1}

Yapının Elemanlarının ve Bölümlerinin Koruma Durumlarının Değerlendirilmesi (Mine Hamamcioğlu Turan, 2020)

\begin{tabular}{|c|c|c|}
\hline $\begin{array}{c}\text { Koruma } \\
\text { Durumu Sınıfı }\end{array}$ & Bulgular & $\begin{array}{c}\text { Müdahale Önceliği ve Müdahalenin } \\
\text { Kapsamı }\end{array}$ \\
\hline DS 3 & $\begin{array}{c}\text { Kismi yıkılma, düşeyden sapma, yapısal } \\
\text { çatlak gibi ileri derecede strüktürel hasar } \\
\text { ve malzeme kaybının yaygın görülmesi. }\end{array}$ & $\begin{array}{c}\text { Riskli; geçici koruyucu çatı oluşturma, } \\
\text { iskele ile destekleme gibi geçici acil } \\
\text { müdahaleler; kapsamlı müdahalenin } \\
\text { planlanması. }\end{array}$ \\
\hline DS 2 & $\begin{array}{c}\text { Yapı bütünlüğü tehdit altında değil, } \\
\text { sinırlı kısımlarda strüktürel hasar; kılcal } \\
\text { çatlak, ufalanma, renk değişimi gibi } \\
\text { malzeme bozulmaları yaygın. }\end{array}$ & $\begin{array}{c}\text { K1sa sürede müdahale; belirli bölgelerde } \\
\text { koruyucu çatı, drenaj gibi önleyici } \\
\text { koruma yapılması; kapsamlı müdahalenin } \\
\text { planlanması. }\end{array}$ \\
\hline DS 1 & $\begin{array}{c}\text { Strüktürel hasar yok, yer yer malzeme } \\
\text { bozulmaları }\end{array}$ & \begin{tabular}{c} 
Uzun sürede müdahale; düzenli izleme. \\
\hline
\end{tabular} \\
\hline
\end{tabular}

Yapı bütünü için koruma durum sınıfı hesaplaması yapılırken; her bir bölgenin kapladığı alan ile bölgenin numarası çarpılmış; çarpımların toplamı alanlar toplamına bölünmüştür: Yap1 Bütünü Koruma Durumu Puanı $=(3$ x 3. bölgedeki yap1 elemanlarının alanı $+2 \times 2$. bölgedeki yapı elemanlarının alanı $+1 \times 1$. bölgedeki yapı elemanlarının alanı) / yap1 elemanlarının toplam alanı.

Elde edilen yapı bütünü koruma durumu puanı; 2,5 ile 3 arasındaki yapılar, 3. derece; 2,5'ten küçük 2'den büyük puan alan yapılar 2. derece, 2 ve altında puan alanlar 1. derece koruma durumu sınıfı olarak değerlendirilmiştir (T. 2).

11 Maria Giovanna Masciotta vd., "A Digital-based Integrated Methodology for the Preventive Conservation of Cultural Heritage: The Experience of HeritageCare Project," International Journal of Architectural Heritage 13 (2019), 10.

12 Mine Hamamcıoğlu Turan ve İpek Akbaylar, "Documentation of Historic Structures for the Assessment of Heritage Characteristics," Journal of Architectural and Planning Research 28/2 (2011), 132. 
Tablo 2

Yap1 Bütünü Koruma Durumu Değerlendirmesi (Mine Hamamc1oğlu Turan, 2020)

\begin{tabular}{|l|l|l|}
\hline $\begin{array}{l}\text { Koruma Durumu } \\
\text { Puanı }\end{array}$ & $\begin{array}{l}\text { Koruma Durumu } \\
\text { Sınıfı }\end{array}$ & Yapının Müdahale Önceliği ve Müdahalenin Kapsamı \\
\hline $2,5-3$ puan & 3 & $\begin{array}{l}\text { Acilen ek inceleme ve teşhislerin tamamlanması, kapsamlı } \\
\text { müdahalelerin planlanması ve gerçekleştirilmesi }\end{array}$ \\
\hline$<2,5,>2$ puan & 2 & $\begin{array}{l}\text { Belirli bölgelere acil müdahale ya da önleyici koruma } \\
\text { yapılması, yapı bütününde ek inceleme ve teşhislerin kısa } \\
\text { zamanda tamamlanması; kapsamlı müdahalenin planlanması }\end{array}$ \\
\hline$\leq 2$ puan & 1 & $\begin{array}{l}\text { Yapının izlenerek, hasar ve bozulmaların yaygınlaşmasının ve } \\
\text { ilerlemesinin engellenmesi }\end{array}$ \\
\hline
\end{tabular}

\section{Yapılar ve Çevreleri Hakkında Bilgiler}

Bu bölümde farklı yapım özellikleri ve koruma durumları sergileyen iki vaka hakkında bilgi verilmesi amaçlanmaktadır.

Matrone Kilisesi ${ }^{13}$ (G. 1), İzmir'in, Çeşme ilçesine bağlı Ildırı' da ${ }^{14}$ bulunmaktadır. Ildırı, İzmir ilinin doğusunda, Çeşme ilçe merkezinin kuzeydoğusunda deniz kıyısında bir köydür. İncelenen yapı köye hâkim bir tepede ve Erythrai arkeolojik sit alanı sınırları içerisindedir ${ }^{15}$. Matrone Kilisesi, 19. yüzyıl sonlarında inşa edilmiş ve 1923 mübadelesinden sonra kilisenin cemaati kalmamıştır. Yap1 1948 yılında dinamitlenmiş ve büyük hasar görmüştür. 1981 yılında alınan ilk kararla, Matrone kilisesinin bulunduğu alan, 1. derece arkeolojik sit olarak tescillenmiştir. Günümüzde kilisenin bulunduğu alan, İzmir I. Nolu Kültür ve Tabiat Varlıklarını Koruma Kurulu’nun, 6.10.1995 tarih ve 5932 say1lı kararı ile 1.derece arkeolojik sit alanı olarak tescillidir ${ }^{16}$. Kilisenin batısında kazı alanı, kuzey ve güney duvarı bitişiğinde sarnıç kalıntıları, doğusunda ise yaklaşık 8 metre ileride teras duvarı kalıntıları görülmektedir. Günümüzde bütünlügüunü kaybetmiş olan kilisenin üç duvarı kısmen ayaktadır. Dikdörtgen planlı yapı (17 x 11,4 m) doğu-batı doğrultusunda uzanmaktadır (G. 3).

13 Hamamcıoğlu Turan ve Akbaylar, "Tarihi Yapıların Değişimlerinin Belgelenmesi ve Bulguların Arşivlenmesi için Fotogrametrik bir Yöntem Araştırması, Yayınlanmamış Araştırma Projesi Raporu”, TÜBİTAK MAG 104 I,102, İzmir, 2007; Proje ekibi Emre İpekci, Gizem Türkarslan, Serpil Bașlılar Altun, Burçin Görür, Canan Durak, N. Mine Tunca, Şeyma Sarıbekiroğlu, Anna Neratzouli ve E. Alexandros Maistralis; yürütücüler Mine Hamamcıoğlu Turan ve Engin Aktaş, 'İzmir, Çeşme, Ildır'daki Matrone Kilisesinin Restorasyonu ve Çevresinin Düzenlenmesi Projesi’, Mimari Restorasyon Tasarımı II dersi, İzmir Yüksek Teknoloji Enstitüsü, İzmir. 2015. http://arch.restoration.iyte.edu.tr/izmir-cesme-ildirdaki-aziz-matrone-kilisesinin-restorasyonu- $v$ e-cevresinin-duzenlenmesi-projesi/.

14 Ildırı'nın adı son yıllarda Ildır olarak değiștirilmiştir. İBB, 2016. Ildır Mahallesi, Çeşme, Coğrafi Sistemleri Şube Müdürlüğü, İzmir, erişim 22 Nisan 2020, https://kentrehberi.izmir.bel.tr/ izmirkentrehberi. Bu çalışmada yaygın olarak bilinen Ildırı adı kullanılmıştır.

15 Azize Matrone ve Ildırı Tarihi Yerleşim Dokusu hakkında daha fazla bilgi için bkz. "Saint Matrona of Chios the Wonderworker," erişim 14 Mayıs 2020, https:/www.johnsanidopoulos.com/2016/10/saint-matrona-ofchios-wonderworker.html; Güzide Budun, "Ildırı Tarihi Dokusunun Araştırılması ve Koruma Amaçlı Değerlendirilmesi” (Yüksek Lisans Tezi, Dokuz Eylül Üniversitesi, 2003); Ela Çil ve F. Nurşen Kul, "Ildırı: Yerleşilemeyen Köy,” Mimarlık 387 (Ocak-Şubat 2015), 381, erişim 18 Haziran 2020, http://www.mimarlikdergisi.com/index.cfm?sayfa=mimarlik\&DergiSayi=395\&RecID=3581.

161964 yılında başlayan kazı çalışmaları, Ankara Üniversitesi tarafından sürdürülmektedir. Ayrıntılı bilgi için bkz. Ekrem Akurgal, Erythrai: An Ancient Ionian City (İzmir: Tifset A.Ş., 1972); Ayşegül Akalın Orbay, “Erythrai'da Ana Tanrıça’nın İzleri II," Ömer Çapar'a Armağan (İstanbul: Hel Yayıncılık, 2012), 1-12; Numan Tuna, "Erythrai Arkeolojik Sit Alanında Koruma Sorunları: Erythrai Örneği,” Ege Mimarlık 6/7 (1992), 43. 


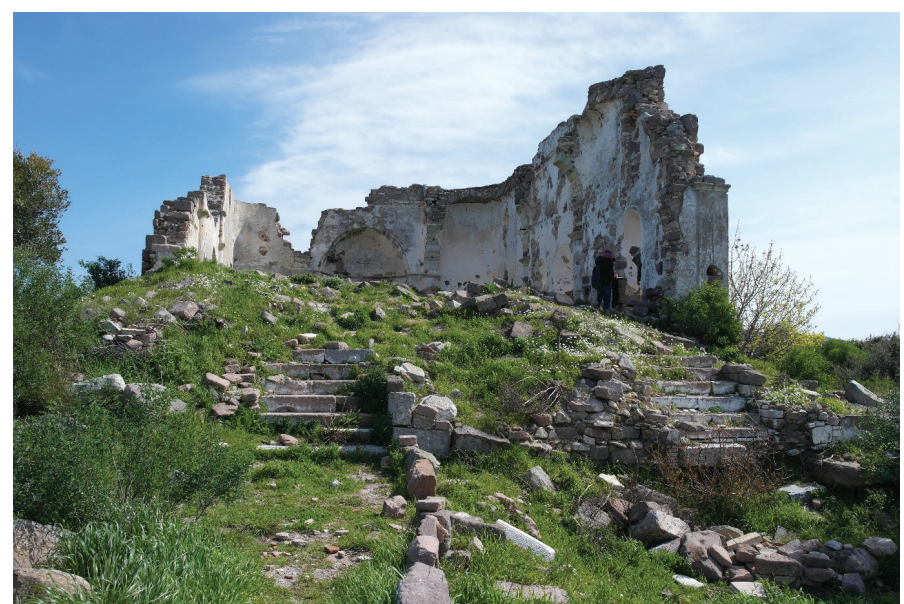

G. 1. Matrone Kilisesi, özgün giriş yönünden bakış (Emre İpekci, 2015)

Tablo 3

Yap1 Bütününün Koruma Durumu, Matrone Kilisesi (Emre İpekci, vd., 2015)

\begin{tabular}{|c|c|c|c|c|c|c|c|c|}
\hline \multicolumn{9}{|c|}{$\begin{array}{l}\text { YAPININ ADI: SAINT } \\
\text { YAPI ELEMANLARI }\end{array}$} \\
\hline \multicolumn{4}{|c|}{ 2. TONOZ KALINTILARI (güneydoğu köß̣øe) } & \multicolumn{2}{|c|}{ 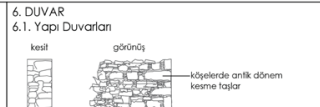 } & \multicolumn{3}{|c|}{ 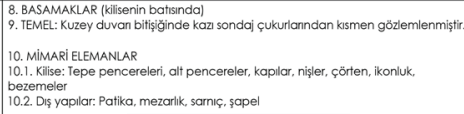 } \\
\hline \multirow{2}{*}{\multicolumn{4}{|c|}{$\begin{array}{l}\text { 3. KEMER KALINTILARI } \\
\text { 4. SÜTUNCELER } \\
\text { 5. GERGI ELEMANLARI } \\
\text { YAPIM TEKNIG̈i VE MALZEME KULLANIMI } \\
\end{array}$}} & \multicolumn{2}{|c|}{ 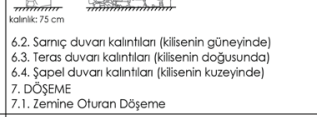 } & \multicolumn{3}{|c|}{ 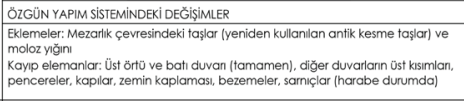 } \\
\hline & & & \multicolumn{6}{|c|}{ YAPIM TEKNIG̈̈i VE MALZEME KULLANMMI } \\
\hline \multicolumn{4}{|c|}{ 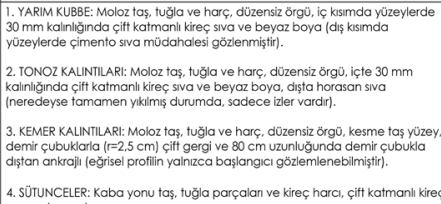 } & 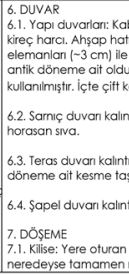 & 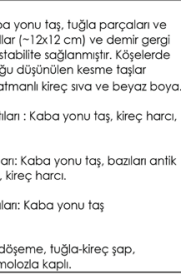 & $\begin{array}{l}\text { 8. BASA } \\
\text { 9. TEMEL } \\
\text { 10. MiM } \\
\text { 10.1. Kills } \\
\text { 10.2. DIs } \\
\text { Patika: } \\
\text { Mezarlik } \\
\text { Sarnc: } \\
\text { Sapel: T }\end{array}$ & 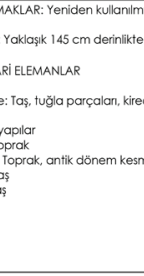 & 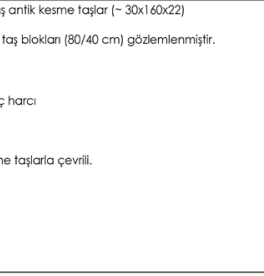 \\
\hline & & Bölgeler & Alan & Yapı Elemanı Sayııı & Yapısal Sorun Tanımı & & Risk Değerlendirmesi & Önerilen Önlem \\
\hline \multirow{3}{*}{ 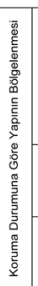 } & 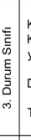 & 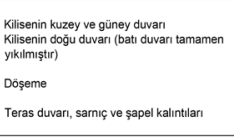 & $\begin{array}{c}10,5 \mathrm{~m}^{2} \text { ve } 13,5 \mathrm{~m}^{2} \\
9,5 \mathrm{~m}^{2} \\
203,5 \mathrm{~m}^{2} \\
5 \mathrm{~m}^{2} \text { ve } 34 \mathrm{~m}^{2}\end{array}$ & $\begin{array}{c}5-5 \\
5 \\
1 \\
3\end{array}$ & 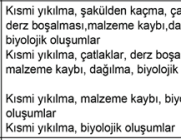 & $\begin{array}{l}\text { ataklar, } \\
\text { ağlma } \\
\text { alması, } \\
\text { oluşumlar } \\
\text { olojik }\end{array}$ & Acil müdahale & $\begin{array}{l}\text { Geçici koruyucu çat, iskele kurulması. } \\
\text { Duvar için kurulan iskele ile yap elemanlanı } \\
\text { güvence altına alinmalidir. } \\
\text { Duvarların stabilitesi sağlandıktan sonra, molozlar } \\
\text { temizlenmelidir. } \\
\text { Duvarlarda bakım, taş koruma }\end{array}$ \\
\hline & 年 & Basamaklar & $8 \mathrm{~m}^{2}$ & 1 & $\begin{array}{l}\text { Malzeme kaybi, kuçü çatiaklar, a } \\
\text { renk değişimi }\end{array}$ & ąıınma, & Kisa dönemde múdahale & Bakim ve basit onarm \\
\hline & 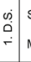 & $\begin{array}{l}\text { Sütunceler (doğu duvarındaki hariç) } \\
\text { Mezarlık (kilisenin batııında) }\end{array}$ & $\begin{array}{l}6 \mathrm{~m}^{2} \\
100 \mathrm{~m}^{2}\end{array}$ & 5 & Malzeme kaybı, renk değişimi & & Orta dönemde müdahale & Bakım ve basit onarım \\
\hline \multirow{2}{*}{ 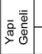 } & \multicolumn{2}{|c|}{ Koruma Durumu } & \multicolumn{4}{|c|}{ Kismen yikılmış, kalıc yapısal hasar ve yaygin malzeme bozulması } & Koruma Durum Puanı & 2,51 \\
\hline & \multicolumn{2}{|c|}{ Onerilen Müdahale } & \multicolumn{4}{|c|}{ Gecici acil múdahale, en kısa zamanda restorasyon } & Koruma Sinffı & 3 \\
\hline
\end{tabular}


Tablo 4

Yapı Elemanlarının Koruma Durumu, Kısmi Tablo, Matrone Kilisesi (Emre İpekci, vd., 2015)

\begin{tabular}{|c|c|c|c|c|c|c|}
\hline \multirow[b]{2}{*}{$\begin{array}{c}\text { Yapı } \\
\text { Elemanları }\end{array}$} & \multirow{2}{*}{$\begin{array}{c}\text { Yapı Elemanı } \\
\text { Açıklaması } \\
\text { (malzemeler, yapım } \\
\text { ve yeri) }\end{array}$} & \multicolumn{2}{|l|}{ Durum } & \multicolumn{3}{|c|}{ Risk Değerlendirmesi ve Öneriler } \\
\hline & & $\begin{array}{c}\text { Durum } \\
\text { Açıklaması }\end{array}$ & $\mathbf{D S}^{17}$ & $\begin{array}{c}\text { Olası sebepler / } \\
\text { sonuçlar }\end{array}$ & $\begin{array}{l}\text { Önerilen } \\
\text { önlemler }\end{array}$ & $\mathbf{A D}^{18}$ \\
\hline Kemer-6 & $\begin{array}{c}\text { Moloz taş, tuğla ve } \\
\text { harç, düzensiz örgü, } \\
\text { kesme taş yüzey, } \\
\text { demir çubuklarla } \\
\text { (r=2,5 cm) çift gergi } \\
\text { ve } 80 \mathrm{~cm} \text { uzunluğunda } \\
\text { demir çubukla diştan } \\
\text { ankrajlı. Sadece alt } \\
\text { kısım gözlenmiştir } \\
\end{array}$ & $\begin{array}{l}\text { Eğrisel profilin } \\
\text { yalnızca } \\
\text { başlangıcı } \\
\text { anlaşılabilmekte, } \\
\text { geri kalan kısmı } \\
\text { yoktur. }\end{array}$ & DS3 & Dinamitleme & $\begin{array}{c}\text { Geçici koruyucu } \\
\text { çatı, iskele } \\
\text { kurulması }\end{array}$ & $\mathrm{AD} 3$ \\
\hline $\begin{array}{c}\text { Tonoz-1 } \\
\text { (Kuzey duvar) }\end{array}$ & $\begin{array}{c}\text { Moloz taş, tuğla } \\
\text { ve harç, düzensiz } \\
\text { örgü, içte } 30 \mathrm{~mm} \\
\text { kalınlığında çift } \\
\text { katmanlı kireç sıva } \\
\text { ve beyaz boya, dışta } \\
\text { horasan sıva } \\
\end{array}$ & $\begin{array}{c}\text { Neredeyse } \\
\text { tamamen } \\
\text { yıkılmış } \\
\text { durumda, sadece } \\
\text { izler vardır. }\end{array}$ & DS3 & Dinamitleme & $\begin{array}{c}\text { Geçici koruyucu } \\
\text { çatı, iskele } \\
\text { kurulması }\end{array}$ & AD3 \\
\hline $\begin{array}{c}\text { Tonoz-2 } \\
\text { (Güney duvar) }\end{array}$ & $\begin{array}{c}\text { Moloz taş, tuğla } \\
\text { ve harç, düzensiz } \\
\text { örgü, içte } 30 \mathrm{~mm} \\
\text { kalınlığında çift } \\
\text { katmanlı kireç sıva } \\
\text { ve beyaz boya, dışta } \\
\text { horasan sıva }\end{array}$ & $\begin{array}{c}\text { Neredeyse } \\
\text { tamamen } \\
\text { yıkılmış } \\
\text { durumda, sadece } \\
\text { izler vardır. }\end{array}$ & DS3 & Dinamitleme & $\begin{array}{c}\text { Geçici koruyucu } \\
\text { çatı, iskele } \\
\text { kurulması }\end{array}$ & $\mathrm{AD} 3$ \\
\hline Yarım kubbe & $\begin{array}{c}\text { Moloz taş, tuğla } \\
\text { ve harç, düzensiz } \\
\text { örgü, içte } 30 \mathrm{~mm} \\
\text { kalınlığında çift } \\
\text { katmanlı kireç sıva } \\
\text { ve beyaz boya, dışta } \\
\text { çimento sıva }\end{array}$ & Büyük çatlaklar & DS3 & $\begin{array}{l}\text { Dinamitleme, doğu } \\
\text { duvarının güneydoğu } \\
\text { kısmında taş kaybı }\end{array}$ & $\begin{array}{c}\text { Geçici koruyucu } \\
\text { çatı, iskele } \\
\text { kurulması }\end{array}$ & $\mathrm{AD} 3$ \\
\hline Döşeme & $\begin{array}{l}\text { Yere oturan döşeme, } \\
\text { tuğla-kireç şap, } \\
\text { neredeyse tamamen } \\
\text { molozla kaplı }\end{array}$ & Bitki büyümesi & DS3 & Dinamitleme & $\begin{array}{c}\text { Duvarların } \\
\text { stabilitesi } \\
\text { sağlandıktan } \\
\text { sonra molozlar } \\
\text { temizlenmelidir } \\
\end{array}$ & $\mathrm{AD} 1$ \\
\hline Basamaklar & $\begin{array}{l}\text { Yeniden kullanılmış } \\
\text { antik kesme taşlar } \\
\quad(\sim 30 \times 160 \times 22)\end{array}$ & Aşınma & DS2 & $\begin{array}{l}\text { Kötü hava etkisi ile } \\
\text { bozulma, yıpranma }\end{array}$ & Taş koruma & AD1 \\
\hline
\end{tabular}

17 DS: Durum Sınıfları (0: sorun bulgusu yok, 1: az sorun bulgusu, 2: orta derecede sorun bulgusu, 3: çok sorun bulgusu)

18 AD: Aciliyet Durumları (0: uzun dönemde ele alınacaklar, 1: orta dönemde ele alınacaklar, 2: kısa dönemde ele alınacaklar, 3: öncelikle ele alınacaklar) 


\section{Tablo 5}

Mimari Elemanların ve Dış Mekân Elemanlarının Koruma Durumu, Kısmi Tablo, Matrone Kilisesi (Emre İpekci, vd., 2015)

\begin{tabular}{|c|c|c|c|c|c|c|}
\hline \multirow[b]{2}{*}{$\begin{array}{c}\text { Yapı } \\
\text { Elemanları }\end{array}$} & \multirow{2}{*}{$\begin{array}{c}\text { Yapı } \\
\text { Elemanı } \\
\text { Açıklaması } \\
\text { (malzemeler, } \\
\text { yapım ve } \\
\text { yeri) }\end{array}$} & \multicolumn{2}{|l|}{ Durum } & \multicolumn{3}{|c|}{ Risk Değerlendirmesi ve Öneri } \\
\hline & & $\begin{array}{c}\text { Durum } \\
\text { Açıklaması }\end{array}$ & $\mathbf{D S}^{19}$ & $\begin{array}{c}\text { Olası sebepler / } \\
\text { sonuçlar }\end{array}$ & $\begin{array}{l}\text { Önerilen } \\
\text { önlemler }\end{array}$ & $\mathbf{A D}^{20}$ \\
\hline $\begin{array}{c}\text { Tepe } \\
\text { penceresi: } \\
\text { Güney } \\
\text { penceresi } 1\end{array}$ & 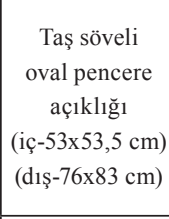 & $\begin{array}{c}\text { Cam veya } \\
\text { kepenk } \\
\text { gözlenmemekte, } \\
\text { içeride açıklık } \\
\text { geometrisinde } \\
\text { kayıp }\end{array}$ & DS3 & Dinamitleme/ eleman kaybı & $\begin{array}{c}\text { Duvar için } \\
\text { kurulan iskele } \\
\text { ile beraber yapı } \\
\text { elemanı güvenceye } \\
\text { alınmalıdır }\end{array}$ & AD3 \\
\hline $\begin{array}{c}\text { Niş: } \\
\text { Doğu duvarı } 1\end{array}$ & $\begin{array}{l}\text { Dikdörtgen niş } \\
(\text { iç}-59 \times 137 \mathrm{~cm})\end{array}$ & $\begin{array}{c}\text { Açıklık } \\
\text { geometrisinde } \\
\text { kısmi kayıp }\end{array}$ & DS2 & Yipranma / eleman kayb1 & $\begin{array}{c}\text { Duvar için } \\
\text { kurulan iskele } \\
\text { ile beraber yapı } \\
\text { elemanı güvenceye } \\
\text { alınmalıdır }\end{array}$ & AD3 \\
\hline Çörten & $\begin{array}{l}\text { Taş çörten } \\
\text { (iç-19x14 cm) }\end{array}$ & $\begin{array}{l}\text { Hasar belirtisi } \\
\text { gözlenmemiştir }\end{array}$ & DS0 & - & - & AD0 \\
\hline \multicolumn{7}{|c|}{ Dış Yapılar } \\
\hline Patika & $\begin{array}{c}\text { Yapıyı } \\
\text { çevreleyen } \\
\text { toprak yol, } \\
\text { düzenli bir } \\
\text { dolaşım şeması } \\
\text { yok }\end{array}$ & $\begin{array}{l}\text { Düzgün olmayan } \\
\text { taşlar dolaşımı } \\
\text { sınırlandırmakta }\end{array}$ & DS2 & Tasarım eksikliği & $\begin{array}{c}\text { Düzgün olmayan } \\
\text { yüzeylerin } \\
\text { düzeltilmesi }\end{array}$ & $\mathrm{AD} 2$ \\
\hline Mezarlık & $\begin{array}{c}\text { Kilisenin batı } \\
\text { tarafında, } \\
\text { Antik dönem } \\
\text { kesme taşlarla } \\
\text { çevrili; kabaca } \\
\text { sınırları belirli }\end{array}$ & $\begin{array}{l}\text { Yaygin malzeme } \\
\text { bozulması }\end{array}$ & DS1 & $\begin{array}{c}\text { Arkeolojik kazı / Kilise için } \\
\text { çevre bilgilerinin kaybı }\end{array}$ & $\begin{array}{c}\text { Sunum stratejisinin } \\
\text { geliştirilmesi }\end{array}$ & $\mathrm{AD} 2$ \\
\hline
\end{tabular}

İkinci ele aldığımız yapı olan Çardak $\operatorname{Han}^{21}$, Denizli il merkezinin doğusunda, Acıgöl'ün hemen batısında bulunan Çardak İlçe merkezinde, geleneksel merkezin güneyindeki Saraylar Mahallesi’nde, Denizli-Afyon Karayolunun kuzeyinde, Dutluca Yolu üzerinde, 24 ada, 12 parselde yer almaktadır (G. 4). Yap1, 1230 yılına tarihlen-

19 DS: Durum Sınıfları (0: sorun bulgusu yok, 1: az sorun bulgusu, 2: orta derecede sorun bulgusu, 3: çok sorun bulgusu)

20 AD: Aciliyet Durumları (0: uzun dönemde ele alınacaklar, 1: orta dönemde ele alınacaklar, 2: kısa dönemde ele alınacaklar, 3: öncelikle ele alınacaklar)

21 Proje ekibi Feyza Durmuşlar, Ayşe Bayram, Canan Nalça, Damla Gül Begüm. Keke, Ebru Özel, Ece Yönetken, Emre Özdemir, Esra Eken, İdil Ece Şener, Merve Ergin, Özüm Birgin ve Veli Mustafa Yönder; Yürütücü Mine Hamamcıoğlu Turan; Danışman: Engin Aktaş, 'Çardak Han’ın Restorasyonu ve ilgili Kültür Rotasının Korunması Projesi’, Mimari Restorasyon Tasarımı II Dersi, İzmir Yüksek Teknoloji Enstitüsü, İzmir, 2017. 
dirilmektedir ${ }^{22} .2006$ yılında temizlik ve kazı çalışmaları yapılmıştır²3. Han, İzmir II Numaralı Kültür ve Tabiat Varlıklarını Koruma Bölge Kurulu'nun 22.05.1991 tarih ve 2024 sayılı kararı ile tescillidir ${ }^{24} .2017$ yılında yapının restorasyonuna başlanmıştır ${ }^{25}$. Hanın, barınak ve avlu çevresindeki servis mekânları olmak üzere iki kısmı vardır. Barınak (25,7 x 21,9 m) doğu-batı yönünde beş sahından oluşmaktadır. Tonozlu üst örtüsü, sağır dış duvarları ve kemer dizileriyle boşaltılmış iç duvarları ayaktadır ${ }^{26}$. Tümüyle yıkılmış olan servis mekânlarının kalıntıları avlunun $(32,19$ x 33,28 m), kuzeyinde ve güneyinde yer almaktadırlar (G. 2, G. 5).

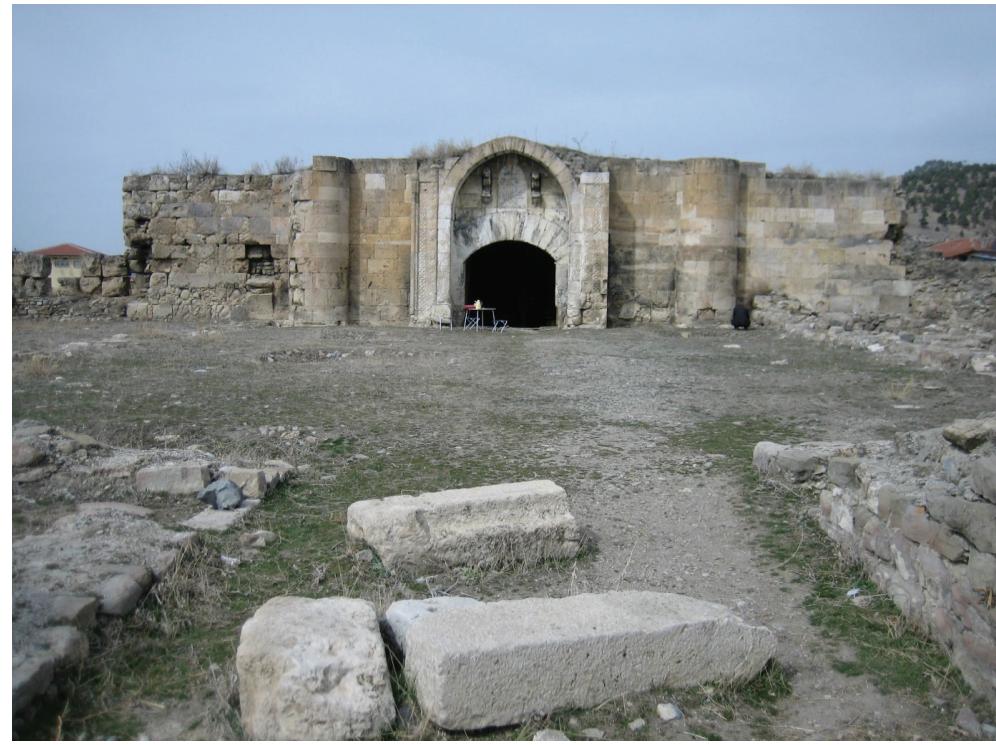

G. 2. Çardak Han, avlu girişinden batıya bakış (Feyza Durmuşlar, 2017)

22 Yapı hakkında ayrıntılı bilgi için bkz. Özkan Ertuğrul, "Çardak Han,” TDV İslam Ansiklopedisi, c. 8 (İstanbul: Türkiye Diyanet Vakfı Yayınları, 1993), 58; Nur Akın, "The Çardak Caravanserai-Denizli” (Yüksek Lisans Tezi, Orta Doğu Teknik Üniversitesi, 1974); Mustafa Beyazıt, "Denizli'de Çardak Han ve Ak Han” (Yüksek Lisans Tezi, Pamukkale Üniversitesi, 2002); Tuncer Baykara, Selçuklular ve Beylikler Çağında Denizli (İstanbul: IQ Kültür Sanat Yayıncılık, 2007), 9; Canan Parla ve Erol Altınsapan, "Atabek Ayaz ve Figürlü Bezemeleriyle Denizli Çardak Han,” Erdem 51 (2008), 209; “İpek Yolu-Kültür Yolu,” ÇEKÜL Anadolu Araştırmaları, erişim 10 Mart 2019, http://www.cekulvakfi.org.tr/files/dosyalar-haber/ipekyolu_harita.pdf.

23 Kadir Pektaş, "Çardak Han," Anadolu Selçuklu Dönemi Kervansarayları (Ankara: Kültür ve Turizm Bakanlığı Yayınları, 2007), 161-173.

24 Denizli'de Çardak Han ve Akhan Araştırma Projesi, Pamukkale Üniversitesi Araştırma Fonu Başkanlığı, Proje No:2001SBE010, 2002; Kasım İnce, “Çardak Han ile İlgili Gözlemler ve Düşünceler," (Hambat (HanAbat) Sempozyumu'nda sunulan bildiri, Denizli, 6-9 Ekim 2004).

25 "Çardak Han Eski İhtişamına Kavuşturulacak," Anadolu Ajansl, 25.10.2017, erişim 30 Nisan 2020. https:// www.aa.com.tr/tr/kultur-sanat/cardak-han-eski-ihtisamina-kavusturulacak-/947145.

26 Yavuz, hanlardaki taşıyıcı sistemi yeniden yorumlamıştır. Yavuz’a göre kervansaraylarda, beşik tonozu taşıyanlar ayaklar değil duvarlardır. İki tonoz arasında boydan boya uzanan duvarlar, sahınlarla bağlantı kurabilmek için kemerlerle boşaltılmıştır ve kemer arasında kalan duvar parçaları ayak kadar daralmıştır. $\mathrm{Bu}$ ayaklaşan parçaların derinlikleri duvar kadardır. Bu konuda daha fazla bilgi için bkz. Ayşııl Tükel Yavuz, "Kervansaraylar," Anadolu Selçukluları ve Beylikler Dönemi Uygarllğı, c. 2 (Ankara: Kültür ve Turizm Bakanlığı Yayınları, 2006), 439-449. 


\section{Tablo 6}

Yapı Bütününün Koruma Durumu, Çardak Han (Feyza Durmuşlar, vd., 2017)

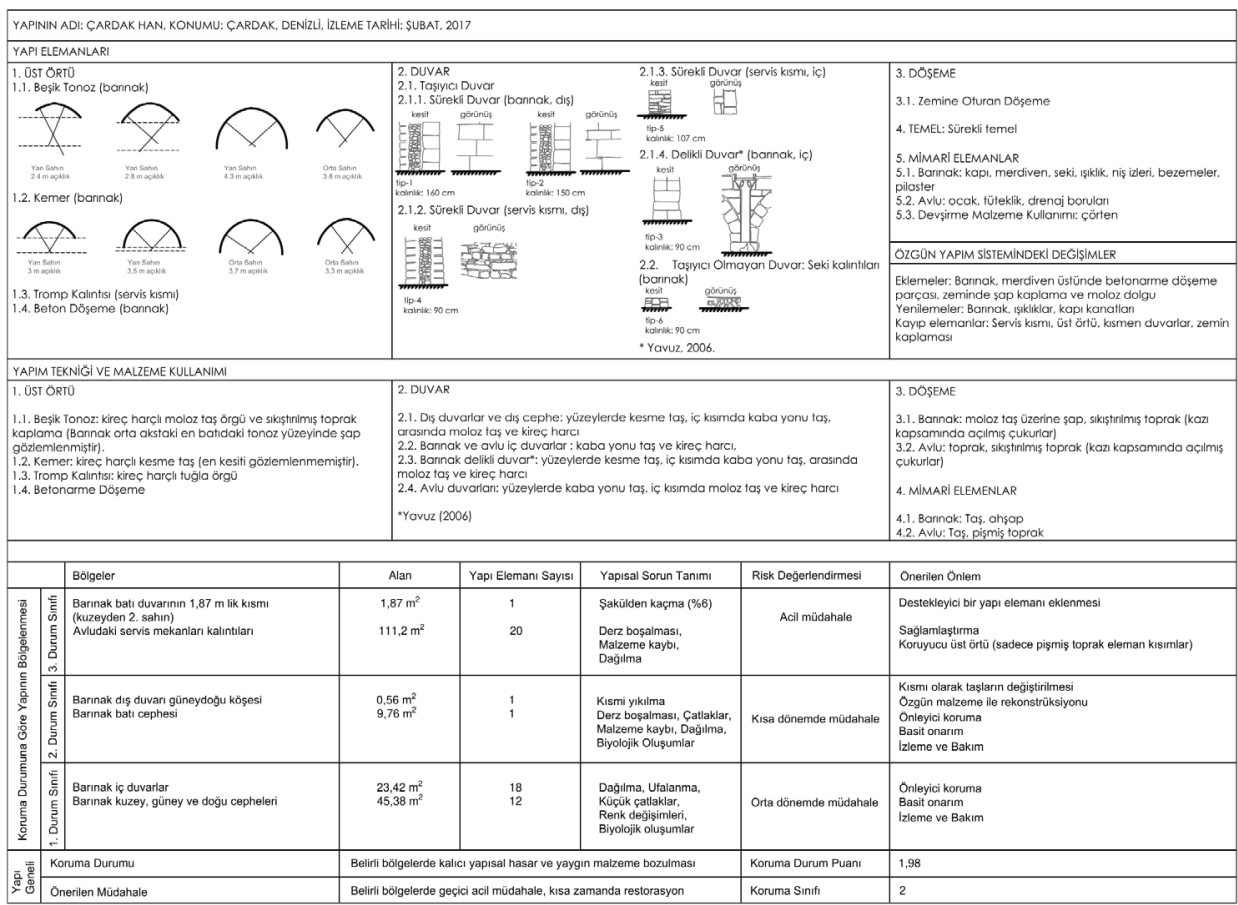

Tablo 7

Yapı Elemanlarının Koruma Durumu, Kısmi Tablo, Çardak Han (Feyza Durmuşlar, vd., 2017)

\begin{tabular}{|c|c|c|c|c|c|c|}
\hline \multirow[b]{2}{*}{$\begin{array}{c}\text { Yapı } \\
\text { Elemanları }\end{array}$} & \multirow{2}{*}{$\begin{array}{c}\text { Yapı } \\
\text { Elemanı } \\
\text { Açılaması } \\
\text { (malzemeler, } \\
\text { yapım ve } \\
\text { yeri) } \\
\end{array}$} & \multicolumn{2}{|l|}{ Durum } & \multicolumn{3}{|c|}{ Risk Değerlendirmesi ve Öneriler } \\
\hline & & $\begin{array}{c}\text { Durum } \\
\text { Açıklaması }\end{array}$ & $\mathbf{D S}^{27}$ & $\begin{array}{c}\text { Olası sebepler / } \\
\text { sonuçlar }\end{array}$ & $\begin{array}{l}\text { Önerilen } \\
\text { önlemler }\end{array}$ & $\mathbf{A D}^{28}$ \\
\hline $\begin{array}{c}\text { Barınak Batı } \\
\text { Dış Duvarı }\end{array}$ & $\begin{array}{l}3 \text { Cidarlı: Dişta } \\
\text { ve içte kaba } \\
\text { yonu taş, ortada } \\
\text { moloz taş, kireç } \\
\text { harcı. }\end{array}$ & $\begin{array}{l}\text { Düşeyden sapma } \\
\text { (en çok \%6: } \\
\text { kuzeyden } 2 . \\
\text { sahında) }\end{array}$ & DS3 & Depremler & $\begin{array}{l}\text { Destekleyici bir } \\
\text { yapı elemanı } \\
\text { eklenmesi }\end{array}$ & AD3 \\
\hline $\begin{array}{c}\text { Servis } \\
\text { mekânlarının } \\
\text { duvarları }\end{array}$ & $\begin{array}{c}\text { Dişta kaba } \\
\text { yonu taş, içte } \\
\text { moloz taş, kireç } \\
\text { harc1. }\end{array}$ & $\begin{array}{l}\text { Büyük oranda } \\
\text { y1kılmış. }\end{array}$ & DS3 & $\begin{array}{c}\text { Depremler, derz } \\
\text { boşalması, malzeme } \\
\text { kaybı, dağılma }\end{array}$ & Sağlamlaştırma ve & AD3 \\
\hline
\end{tabular}

27 DS: Durum Sinıfları (0: sorun bulgusu yok, 1: az sorun bulgusu, 2: orta derecede sorun bulgusu, 3: çok sorun bulgusu)

28 AD: Aciliyet Durumları (0: uzun dönemde ele alınacaklar, 1: orta dönemde ele alınacaklar, 2: kısa dönemde ele alınacaklar, 3: öncelikle ele alınacaklar) 


\begin{tabular}{|c|c|c|c|c|c|c|}
\hline $\begin{array}{l}\text { Kuzey doğu } \\
\text { köşedeki } \\
\text { hamam }\end{array}$ & $\begin{array}{l}\text { Tuğla ayak, } \\
\text { pişmiş toprak } \\
\text { tüteklik ve } \\
\text { künk. }\end{array}$ & $\begin{array}{c}\text { Kalıntı } \\
\text { durumunda. }\end{array}$ & DS3 & $\begin{array}{l}\text { Depremler, derz } \\
\text { boşalması, malzeme } \\
\text { kaybı, dağılma }\end{array}$ & Koruyucu üst örtü & AD3 \\
\hline $\begin{array}{l}\text { Barınak } \\
\text { Doğu Dış } \\
\text { Duvarı }\end{array}$ & $\begin{array}{l}3 \text { Cidarlı: Dişta } \\
\text { kesme taş, içte } \\
\text { kaba yonu taş, } \\
\text { ortada moloz } \\
\text { taş, kireç harcı. }\end{array}$ & $\begin{array}{l}\text { Köşelerde kesme } \\
\text { taşlar eksiltilmiş, } \\
\text { orta kısımda } \\
\text { çatlaklar }\end{array}$ & DS2 & Vandalizm & $\begin{array}{l}\text { Özgünle uyumlu } \\
\text { malzeme ile } \\
\text { bütünleme }\end{array}$ & AD2 \\
\hline Barınak çatısı & $\begin{array}{c}\text { Moloz taş } \\
\text { tonoz üzerine } \\
\text { sıkıştırılmış } \\
\text { toprak, } \\
\text { üzerine beton. } \\
\text { Merdiven } \\
\text { çıkışında } \\
\text { betonarme } \\
\text { döşeme parçası }\end{array}$ & Aşınma & DS2 & $\begin{array}{l}\text { Kötü hava etkisi ile } \\
\text { bozulma, yıpranma }\end{array}$ & Taş koruma & AD1 \\
\hline $\begin{array}{l}\text { Barınak } \\
\text { merdiveni }\end{array}$ & Kesme taş & Aşınma & DS2 & $\begin{array}{l}\text { Kötü hava etkisi ile } \\
\text { bozulma, yıpranma }\end{array}$ & Taş koruma & AD1 \\
\hline $\begin{array}{c}\text { Barınak } \\
\text { Kuzey Dış } \\
\text { Duvarı }\end{array}$ & $\begin{array}{l}3 \text { Cidarlı: Dişta } \\
\text { ve içte kaba } \\
\text { yonu taş, ortada } \\
\text { moloz taş, kireç } \\
\text { harcı. }\end{array}$ & Çatlaklar & DS1 & $\begin{array}{c}\text { Renk değişimi, biyolojik } \\
\text { oluşumlar, dağılma, } \\
\text { ufalanma }\end{array}$ & $\begin{array}{c}\text { Önleyici koruma, } \\
\text { basit onarım. }\end{array}$ & AD1 \\
\hline $\begin{array}{c}\text { Barınak } \\
\text { Güney D1ş } \\
\text { Duvarı }\end{array}$ & $\begin{array}{l}3 \text { Cidarlı: Dişta } \\
\text { kesme taş, içte } \\
\text { kaba yonu taş, } \\
\text { ortada moloz } \\
\text { taş, kireç harcı. }\end{array}$ & Çatlaklar & DS1 & $\begin{array}{c}\text { Renk değişimi, biyolojik } \\
\text { oluşumlar, dağılma, } \\
\text { ufalanma }\end{array}$ & $\begin{array}{c}\text { Önleyici koruma, } \\
\text { basit onarım. }\end{array}$ & AD1 \\
\hline $\begin{array}{l}\text { Barınak } \\
\text { zemin } \\
\text { döşemesi }\end{array}$ & $\begin{array}{c}\text { Alttan üste: } \\
\text { Sikıştırılmış } \\
\text { toprak, moloz } \\
\text { taş, şap, moloz } \\
\text { tabakası. }\end{array}$ & - & - & $\begin{array}{l}\text { Kazı çalışmaları } \\
\text { sırasında açılmış } \\
\text { çukurlar }\end{array}$ & $\begin{array}{c}\text { Duvarların } \\
\text { bakım ve onarımı } \\
\text { sağlandıktan sonra } \\
\text { zemindeki moloz ve } \\
\text { şap temizlenmelidir. }\end{array}$ & AD1 \\
\hline
\end{tabular}

\section{Tablo 8}

Mimari Elemanların ve Dış Mekân Elemanlarının Koruma Durumu, Kısmi Tablo, Çardak Han (Feyza Durmuşlar, vd., 2017)

\begin{tabular}{|c|c|c|c|c|c|c|}
\hline \multirow{2}{*}{$\begin{array}{c}\text { Yapı } \\
\text { Elemanları }\end{array}$} & \multirow{2}{*}{$\begin{array}{c}\text { Yapı Elemanı } \\
\text { Açıklaması } \\
\text { (malzemeler, } \\
\text { yapım ve yeri) }\end{array}$} & \multicolumn{2}{|c|}{ Durum } & \multicolumn{3}{|c|}{ Risk Değerlendirmesi ve Öneri } \\
\hline & & $\begin{array}{c}\text { Durum } \\
\text { Açıklaması }\end{array}$ & $\mathbf{D S}^{29}$ & $\begin{array}{c}\text { Olası sebepler / } \\
\text { sonuçlar }\end{array}$ & & $\mathbf{A} \mathbf{D}^{30}$ \\
\hline $\begin{array}{c}\text { Niş: } \\
\text { Avlu (doğu } \\
\text { duvarı) }\end{array}$ & $\begin{array}{l}\text { Dikdörtgen niş } \\
\text { (iç-50x88 cm) }\end{array}$ & $\begin{array}{c}\text { Kısmen } \\
\text { yıkışmıştır. }\end{array}$ & DS2 & $\begin{array}{l}\text { Yipranma / } \\
\text { eleman kaybı }\end{array}$ & $\begin{array}{l}\text { Malzeme koruma } \\
\text { uygulaması } \\
\text { yapılmalıdır. }\end{array}$ & AD3 \\
\hline
\end{tabular}

29 DS: Durum Sınıfları (0: sorun bulgusu yok, 1: az sorun bulgusu, 2: orta derecede sorun bulgusu, 3: çok sorun bulgusu)

30 AD: Aciliyet Durumları (0: uzun dönemde ele alınacaklar, 1: orta dönemde ele alınacaklar, 2: kısa dönemde ele alınacaklar, 3: öncelikle ele alınacaklar) 


\begin{tabular}{|c|c|c|c|c|c|c|}
\hline $\begin{array}{c}\text { Barınak } \\
\text { Portali }\end{array}$ & $\begin{array}{c}\text { Dikdörtgen niş } \\
\text { (h: } 670 \text {, en: } 370 \\
\mathrm{~cm})\end{array}$ & $\begin{array}{c}\text { Yaygın malzeme } \\
\text { bozulması } \\
\text { gözlemlenmiştir. }\end{array}$ & DS2 & $\begin{array}{c}\text { Hava koşulları } \\
\text { ve suyun nüfuz } \\
\text { etmesine bağlı } \\
\text { olarak kırılma, } \\
\text { parçalanma, siyah } \\
\text { tabaka ve patina } \\
\text { oluşumu }\end{array}$ & $\begin{array}{c}\text { Malzeme koruma } \\
\text { uygulaması } \\
\text { yapılmalıdır. }\end{array}$ & AD2 \\
\hline Bezemeler & $\begin{array}{c}\text { Barınak orta } \\
\text { tonozunun } \\
\text { kemerlere } \\
\text { oturduğu } 3 \text { yerde } \\
\text { yer alan figürler }\end{array}$ & $\begin{array}{c}\text { Bozulma } \\
\text { gözlemlenmiştir. }\end{array}$ & DS2 & $\begin{array}{c}\text { Hava koşulları } \\
\text { ve suyun nüfuz } \\
\text { etmesine bağlı } \\
\text { olarak kırılma, } \\
\text { parçalanma, siyah } \\
\text { tabaka ve patina } \\
\text { oluşumu }\end{array}$ & $\begin{array}{c}\text { Malzeme koruma } \\
\text { uygulaması } \\
\text { yapılmalıdır. }\end{array}$ & $\mathrm{AD} 2$ \\
\hline \multicolumn{7}{|c|}{ Diş Yapılar } \\
\hline Avlu & $\begin{array}{l}\text { Avluda hem duvar } \\
\text { kalıntıları hem de } \\
\text { kemer ayaklarının } \\
\text { izleri var }\end{array}$ & $\begin{array}{c}\text { Yıkılmış, harabe } \\
\text { durumunda }\end{array}$ & DS3 & $\begin{array}{c}\text { Tamamen yok } \\
\text { olma riskine sahip }\end{array}$ & $\begin{array}{l}\text { Yapı elemanı } \\
\text { güvenceye } \\
\text { alınmalıdır }\end{array}$ & AD3 \\
\hline Patika & $\begin{array}{c}\text { Yapıyı çevreleyen } \\
\text { toprak yol, } \\
\text { düzenli bir } \\
\text { dolaşım şeması } \\
\text { yok }\end{array}$ & $\begin{array}{c}\text { Düzgün } \\
\text { olmayan taşlar } \\
\text { dolaşımı } \\
\text { sınırlandırmakta }\end{array}$ & DS2 & Tasarım eksikliği & $\begin{array}{c}\text { Düzgün olmayan } \\
\text { yüzeylerin } \\
\text { düzeltilmesi }\end{array}$ & $\mathrm{AD} 2$ \\
\hline
\end{tabular}

Hem kilisede hem de handa malzeme analizleri sonucunda malzeme türlerinin kendi içlerinde benzer özellikler gösterdiği, değerlerin birbirine çok yakın olduğu görülmüştür. Bu doğrultuda, yapıların farklı bölgelerinin aynı dönemde yapıldığı sonucuna ulaşılmıştır.

\section{Durum Sinıfları ve Risk Değerlendirmesi}

Üst örtüsü, bir dış duvarı, iç mekândaki sütunları yok olmuş, önündeki mezarlık, bitişiğindeki sarnıç tanımsız hâle gelmiş olan; dolayısıyla bütünlüğü ortadan kalkmış ve iklim koşullarına açık durumdaki kilisenin; tamamına yakını üçüncü durum sınıfindadır (276 m²/ 370 m²$^{2}$, toplam 19 yapı elemanı) (G. 3, G. 4, G. 7). Söz konusu ağır hasarlı alanların büyüklüğü, yapı bütününün üçüncü durum sınıfında olmasıyla sonuçlanmıştır. Kilise geneli koruma durumu puanı, giriş bölümünde belirtilen formüle göre hesaplanmış; koruma durumu sınıfı da Tablo 2'deki sınıflandırmaya göre belirlenmiştir:

Kilisenin koruma durumu puan1 $=(3 \times 276)+(2 \times 8)+(1 \times 86) / 370=2,51$ 


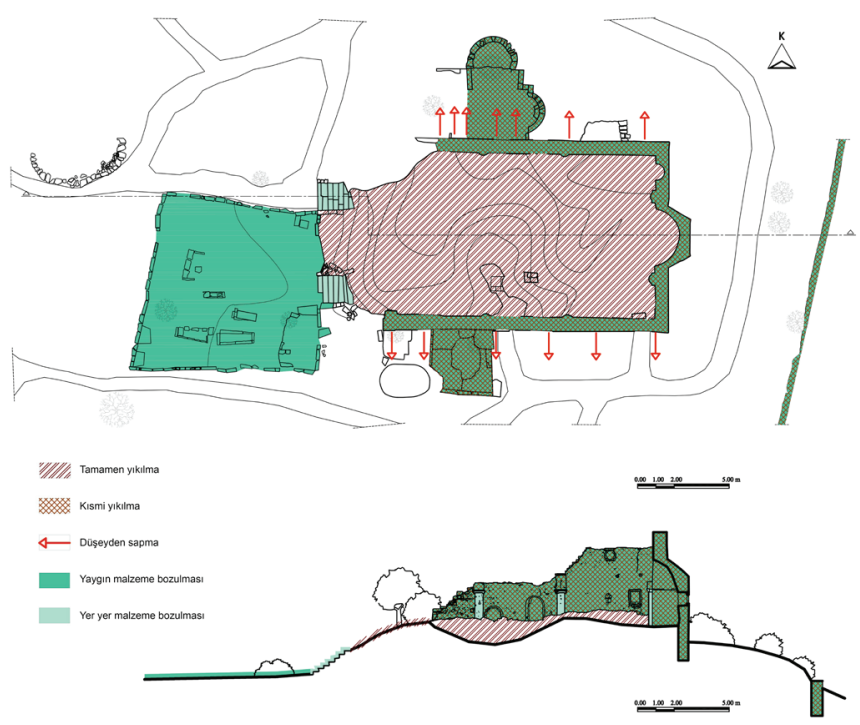

G. 3. Matrone Kilisesi, Strüktürel Hasar ve Malzeme Bozulması (Emre İpekci, vd., 2015)

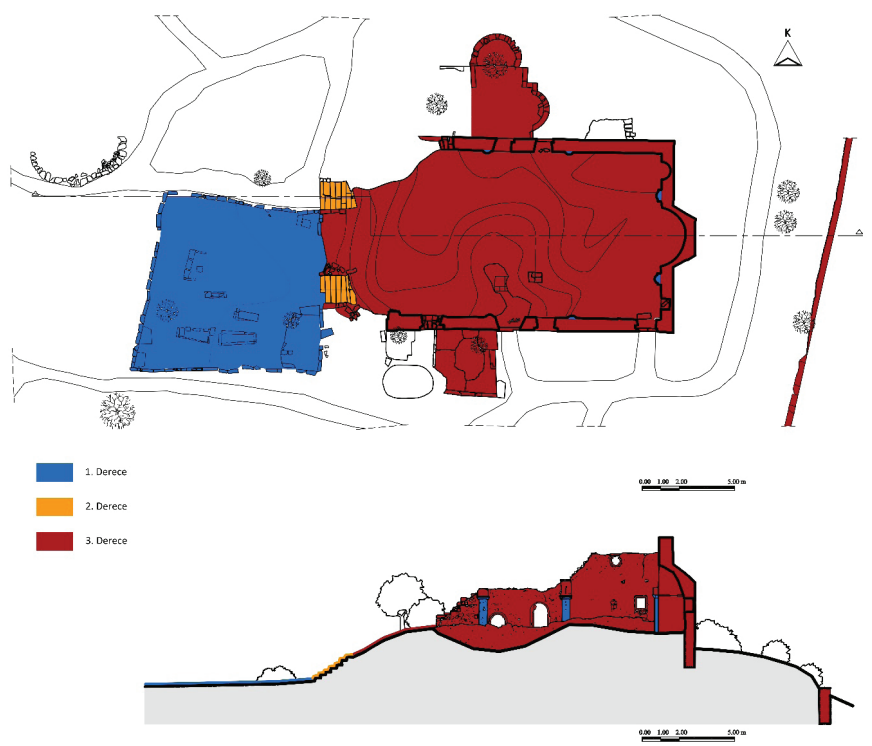

G. 4. Matrone Kilisesi, Durum Sınıfları, Plan ve Kesit (Emre İpekci, vd., 2015)

Diğer yandan kervansaray örneğinin ana bileşeni olan barınak, batı duvarında düşeyden sapma (\%6) görülmekle birlikte, yapısal bütünlügünü korumuş olup önemli bir kısmı birinci durum sinıfindadır (712,2 $\mathrm{m}^{2}$, toplam 68 yapı elemanı) (G. 5, G. 6). Ancak avlu çevresindeki servis mekânlarının $\left(693 \mathrm{~m}^{2}\right)$ harabe durumunda olmaları ve barınak batı duvarında, kuzeyden ikinci sahına karşılık gelen kısımda \%6'ya ulaşan 
düşeyden sapma olması nedeniyle (G. 5), yapı bütünü koruma durumu, Tablo 2'deki sinıflandırmaya göre ikinci durum sinıfinda yer almıştır.

Hanın koruma durumu puan $1=(3 \times 693)+(2 \times 416,5)+(1 \times 712,2) / 1821,7=1,98$

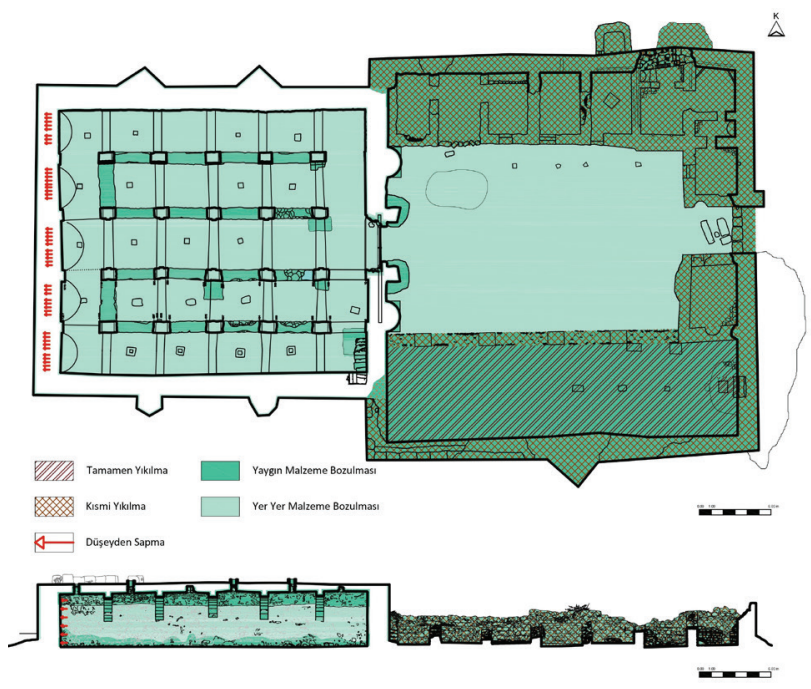

G. 5. Çardak Han, Strüktürel Hasar ve Malzeme Bozulması (Feyza Durmuşlar, vd., 2017)

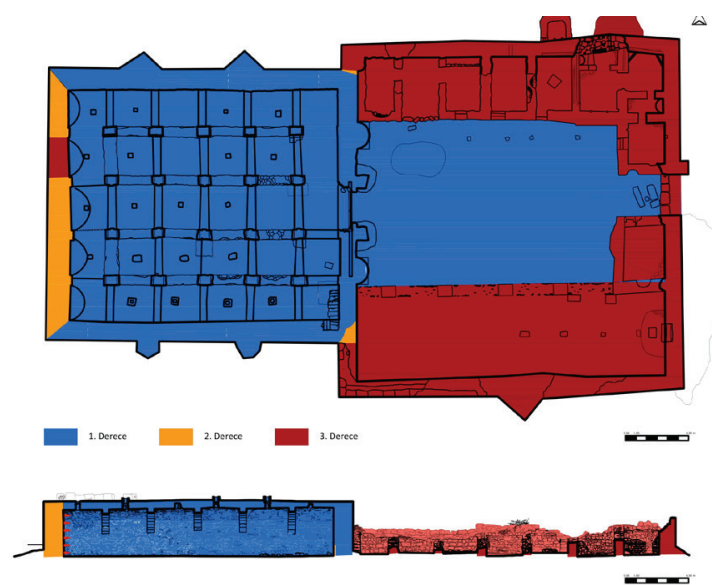

G. 6. Çardak Han, durum sınıfları, plan ve kesit (Feyza Durmuşlar, vd., 2017) 

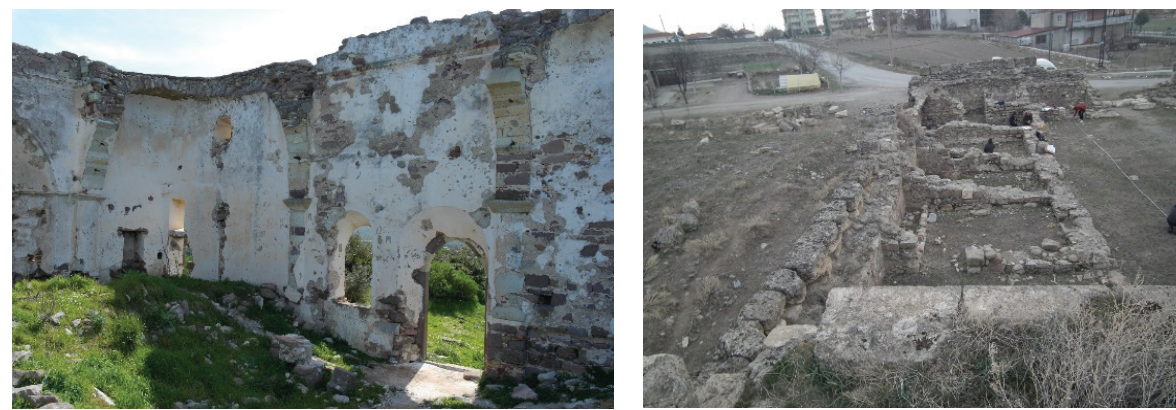

G. 7. Üçüncü Durum Sınıfındaki Bölgeler, solda kilisenin naosu (Emre İpekci, 2015), sağda Çardak Hanın servis mekânları (Feyza Durmuşlar, 2017)

İkinci durum sınıfındaki bölgeler, kilisede ve handa sınırlı miktardadır (sırasıyla $8 \mathrm{~m}^{2}$ ve $39 \mathrm{~m}^{2}$ ). Kilisenin girişindeki kesme taş basamaklar; yer yer çatlaklar, parça kayıpları, ufalanma ve biyolojik oluşumlar içermekle birlikte bu hasar ve bozulmalar yapı bütünlügünü tehdit eder nitelikte değildir (G. 8). Çardak Han, barınak kuzey duvarı, dış köşeleri bazı kesme taş blokların yerinden çıkarılmış olması sebebiyle zayıflamıştır (G. 8). Ancak duvar kesitinin kalınlığı sebebiyle, bu hasarlar yapı bütünlügünü hâlihazırda tehdit eder durumda görülmemiştir. Barınak batı duvarındaki düşeyden sapma ise, kuzeyden ikinci sahına karşılık gelen kısım haricinde, yapısal bütünlüğü tehdit eder miktarda değildir. Dolayısıyla, bu kısımlar Tablo 1'deki sınıflandırmaya göre, ikinci durum sınıfında değerlendirilmiştir.
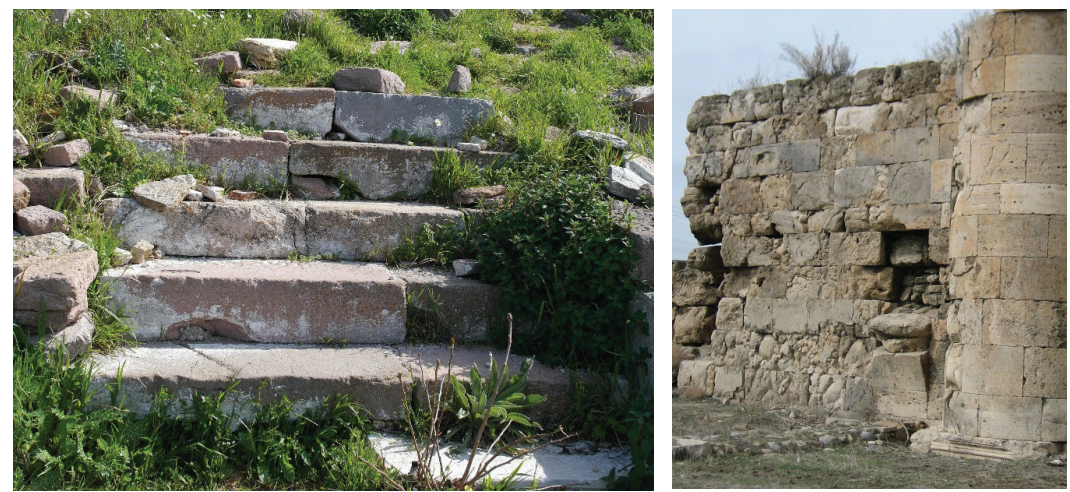

G. 8. İkinci Durum Sınıfındaki Bölgeler, solda kilisenin merdiveni (Emre İpekci, 2015), sağda Çardak Han barınak kuzey duvarı, güneydoğu köşesi (Feyza Durmuşlar, 2017)

Kilisede Tablo 2'deki sınıflandırmaya göre, birinci durum sınıfında yer alan elemanlar; sütunceler ve kilisenin mezarlığıdır ( $86 \mathrm{~m}^{2}$, toplam 5 yapı elemanı). Başlıklarının ve üzerlerindeki kemer kalıntılarının çatı görevi görmesi sebebiyle, göreceli olarak daha iyi korunmuşlardır (G. 8). Yer yer sıva kaybı ve renk değişimi gözlemlenmiştir. Handa ise barınak kısmındaki tonozlarda, kemerlerde ve batı duvarı haricindeki duvarlarda (712,2 $\mathrm{m}^{2}$, toplam 68 yapı elemanı), çatıdan nüfuz eden yağmur suyuna 
ve çatıda beton müdahale malzemesinin kullanımına bağlı olarak tuzlanma olmuştur. Barınak duvarlarının zemine yakın bölgelerinde drenaj sorunları ve zemine şap dökülmesi nedenleriyle, yerden yükselen nem, tuzlanma, küçük çatlak oluşumu, ufalanma, derz boşalması ve malzeme kayıpları olmuştur. Duvarların orta bölümlerinde ise rutubet etkisine bağlı olarak küçük çatlaklar ve renk değişimleri olmuştur (G. 9).
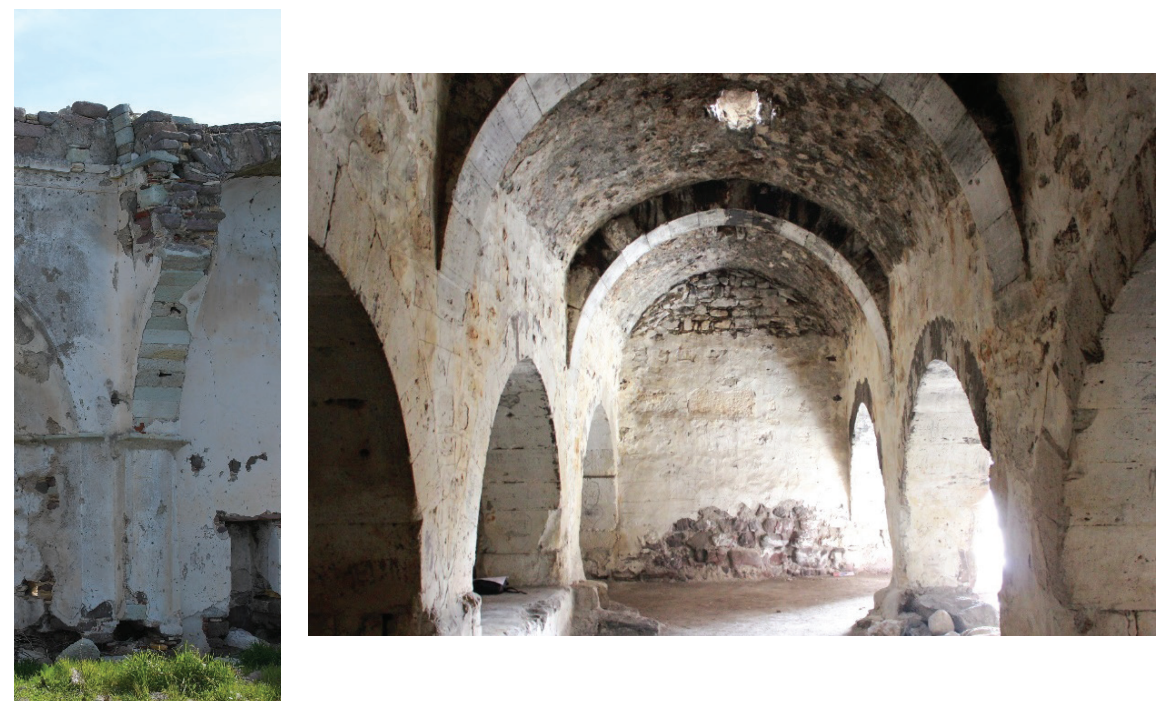

G. 9. Birinci Durum Sınıfındaki Bölgeler, solda kilisenin bir sütuncesi (Emre İpekci, 2015), sağda hanın barınak kısmındaki tonoz, kemer ve duvarlar (Feyza Durmuşlar, 2017)

\section{Müdahale Önerileri}

Her iki yapıda üçüncü durum sınıfında bulunan ve acil müdahale gerektiren bölgeler (T. 1), strüktürel destek elemanları yerleştirilerek güçlendirilmelidir (G. 10). Üst örtüsünü yitirmiş olan ve toprak kökenli malzemeden oluşan kısımlara geçici koruyucu çatı uygulanmalıdır (G. 11). Bunu takiben, yapı bütünü 3. durum sınıfında yer alan kilisede; inşaat mühendisliğ $i^{31}$ ve malzeme koruma disiplinleri çerçevesinde gerekli ek inceleme ve teşhisler acilen tamamlanmalı, kapsamlı müdahale planlanmalıdır. Yapı bütünü 2. durum sınıfında yer alan hanın restorasyonu da kısa zamanda yapılmalıdır.

31 Yapıda, inşaat mühendisliği kapsamında yapılan incelemeler için bkz. Esra Şahin, "Structural Analyses and Assessment of Historical Çardak Caravanserai in Denizli" (Yüksek Lisans Tezi, İzmir Yüksek Teknoloji Enstitüsü, 2019), 52. 

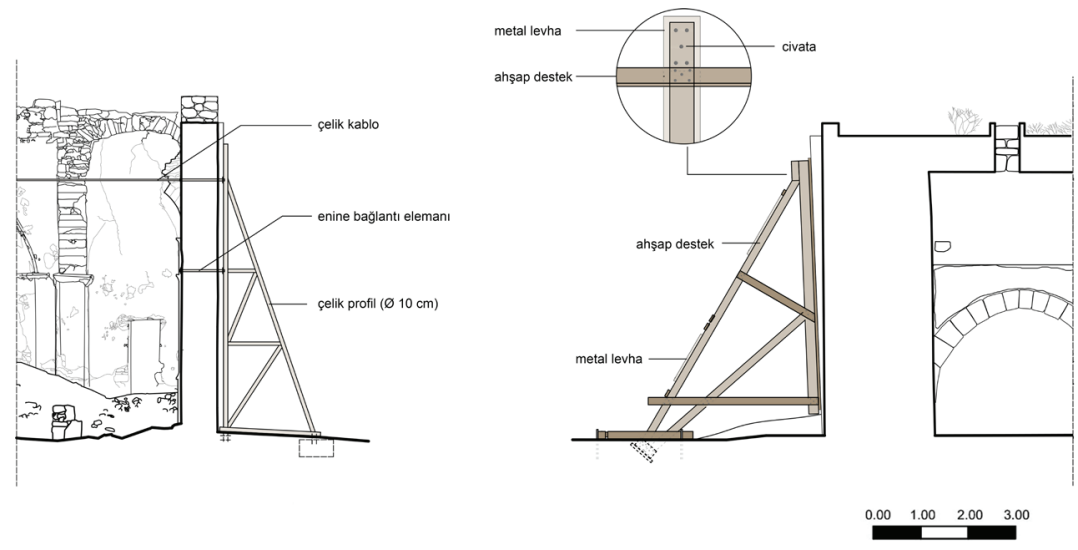

G. 10. Geçici Strüktürel Destek Elemanları, solda kilise (Emre İpekci, vd, 2015), sağda han, boyuna kısmi kesit² (Feyza Durmuşlar, vd, 2017)

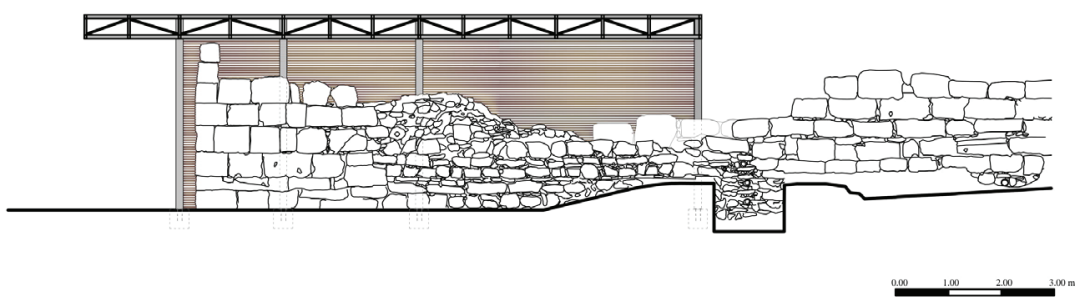

G. 11. Geçici Koruyucu Çat1, han, kuzeydoğu köşe, yan cephe ${ }^{33}$ (Feyza Durmuşlar, vd, 2017)

\section{Sonuç}

Çalı̧̧ma kapsamında incelenen Matrone Kilisesi'nde temel koruma sorunu, yapısal bütünlüğün ortadan kalkması ve yapının tümüyle iklim koşullarına açık hâle gelmesidir. Çardak Handa ise kompozisyonu oluşturan iki parçadan biri bütünlüğünü korurken, diğeri yıkılarak iklim koşullarına açık hâle gelmiştir. Bu durumda giriş bölümünde sunulan sınıflandırmaya göre, kilisenin yapı bütünü durum sınıfı üçtür. Acilen geçici müdahalelerin gerçekleştirilmesi ve kapsamlı onarımın planlanması gereklidir. Han bütününün durum sınıfı ise ikidir. Belirli bölgelerde acil müdahalelerin yapılması, kısa zamanda da kapsamlı müdahalenin planlanması önemlidir.

Benzer nitelikteki tarihsel yığma yapıların hâlihazır koruma durumunun izlenmesi ilkeleri şu şekilde önerilmektedir:

32 İzmir Yüksek Teknoloji Enstitüsü, Mimari Restorasyon Anabilim Dalı’nda verilen Mimari Restorasyon Tasarımı II dersi, 2016-2017 bahar dönemi öğrencisi Ayşe Bayram tarafından çizilmiştir.

33 İzmir Yüksek Teknoloji Enstitüsü, Mimari Restorasyon Anabilim Dalı’nda verilen Mimari Restorasyon Tasarımı II dersi, 2016-2017 bahar dönemi öğrencisi Emre Özdemir tarafından çizilmiştir. 
- Özgün yapım özelliklerinin ve ilgili hasarların doğru kavranması, kültür varlığ1 olan tarihsel yığma yapıların sürdürülebilmesi için önceliklidir.

- Her tarihsel yığma yapı için, genel bir koruma durumu sınıfı tanımlanması ve risk değerlendirmesi, Avrupa standartlarını ve mimari restorasyon alanındaki güncel gelişimleri dikkate alan ancak ülkemiz örneklerine özgü olarak geliştirilecek ölçütler ve terimler çerçevesinde yapılmalıdır. Böylece kültür varlıklarının birbirleriyle kıyaslamalı olarak hasar durumlarının değerlendirilmesi mümkün olacaktır. Müdahaleler, doğru sırada ve kapsamda, gerekli disiplinlerin katılımı ile planlanabilecektir.

- Hâlihazır koruma durumu izlenirken kademeli bir yaklaşımla müdahale sürecinin öncelikleri ve genel çerçevesi belirlenmelidir: Yapı elemanlarındaki farklı hasar durumları belirlenen ölçütler çerçevesinde tek tek incelenmeli; bu elemanlar arasındaki ilişkiler dikkate alınarak farklı koruma durumu bölgeleri belirlenmeli; yapı bütünü için korumu durumu değerlendirilmelidir.

- Hâlihazır koruma durumu izlencesi; yapım özellikleri, koruma durumu, risk değerlendirmesi, müdahale öncelikleri gibi kavramları vurgulamanın yanı sıra konvansiyonel analitik belgeleme süreci ile uyumlu olmalı; koruma uzmanının aşina olduğu sunum biçimlerini içermelidir.

Sonuç olarak belirtilen ilkeler çerçevesinde tarihsel yığma yapıların hâlihazır koruma durumunun izlenmesi; koruma alanı içinde yer alan, farklı disiplinlerden meslek insanları arasında dil birliğini arttıracak ve verilerin karşılaştırılmasını kolaylaştıracaktır. Böylece düzenli bakım ve sürdürülebilir koruma mümkün olabilecektir.

Hakem Değerlendirmesi: Dış bağımsız.

Çıkar Çatışması: Yazarlar çıkar çatışması bildirmemiştir.

Finansal Destek: Yazarlar bu çalışma için finansal destek almadığını beyan etmiştir.

Peer-review: Externally peer-reviewed.

Conflict of Interest: The authors have no conflict of interest to declare.

Grant Support: The authors declared that this study has received no financial support. 


\section{Kaynakça/References}

Akalın Orbay, Ayşegül. “Erythrai'da Ana Tanrıça'nın İzleri II.” Ömer Çapar'a Armağan. İstanbul: Hel Yayınc1lık, 2012, 1-12.

Akın, Nur. "The Çardak Caravanserai-Denizli.”Yüksek Lisans Tezi, Orta Doğu Teknik Üniversitesi, 1974.

Akurgal, Ekrem. Erythrai: An Ancient Ionian City. İzmir: Tifset A.Ş, 1972.

Arığlu, Nihal ve Seden Acun. "A Research About a Method for Restoration of Traditional Lime Mortars and Plasters: A Staging System Approach.” Building and Environment 41 (2006): 12231230.

Baykara, Tuncer, Selçuklular ve Beylikler Çağında Denizli. İstanbul: IQ Kültür Sanat Yayıncılık, 2007.

Beyazıt, Mustafa. "Denizli’de Çardak Han ve Ak Han.” Yüksek Lisans Tezi, Pamukkale Üniversitesi, 2002.

Borri, Antoni, G. Castori, M. Corradi and A. De Maria. "A Method for the Analysis and Classification of Historic Masonry," Bullettin of Earthquake Engineering 13 (2015): 2647-2665.

Budun, Güzide. "Ildırı Tarihi Dokusunun Araştırılması ve Koruma Amaçlı Değerlendirilmesi." Yüksek Lisans Tezi, Dokuz Eylül Üniversitesi, 2003.

Comité Européen de Normalisation, UNI EN 16096 (English): Conservation of Cultural PropertyCondition Ssurvey and Report of Built Cultural Heritage, Brussels, 2012.

"Çardak Han Eski İhtişamına Kavuşturulacak." Anadolu Ajansı, 25 Ekim 2017. Erişim 30 Nisan 2020. https://www.aa.com.tr/tr/kultur-sanat/cardak-han-eski-ihtisamina-kavusturulacak-/947145.

ÇEKÜL Anadolu Araştırmaları, "İpek Yolu-Kültür Yolu”. Erişim 10 Mart 2019. http://www.cekulvakfi.org.tr/files/dosyalar-haber/ipekyolu_harita.pdf.

Çil, Ela ve F. Nurşen Kul. "Ildırı: Yerleşilemeyen Köy,” Mimarlık 387 (Ocak-Şubat 2015). Erişim 18 Haziran 2020. http://www.mimarlikdergisi.com/index.cfm?sayfa=mimarlik\&DergiSayi=39 $5 \& \operatorname{RecID}=3581$

Hamamcioğlu Turan, Mine ve İpek Akbaylar. "Documentation of Historic Structures for the Assessment of Heritage Characteristics." Journal of Architectural and Planning Research 28/2 (2011): 129-151.

Hamamcıoğlu-Turan, Mine (Yürütücü) ve İpek Akbaylar (Araştırmacı), “Tarihi Yapıların Değişimlerinin Belgelenmesi ve Bulguların Arşivlenmesi için Fotogrametrik bir Yöntem Araştırması, Yayınlanmamış Araştırma Projesi Raporu”, Destekleyen Kurum: TÜBİTAK, Proje Kodu: MAG 104 I 102, İzmir, 2007.

İnce, Kasım. “Çardak Han ile İlgili Gözlemler ve Düşünceler.” (Han-Abat) Sempozyumu'nda sunulan bildiri, Denizli, 6-9 Ekim 2004.

İnce, Kasım. Denizli'de Çardak Han ve Akhan Araştırma Projesi, Pamukkale Üniversitesi Araştırma Fonu Başkanlığı, Proje No: 2001SBE010, 2002.

John Sanidopoulos. "Saint Matrona of Chios the Wonderworker." Erişim 14 Mayıs 2020. https:// www.johnsanidopoulos.com/2016/10/saint-matrona-of-chios-wonderworker.html.

Özkan Ertuğrul. "Çardak Han.” TDV İslam Ansiklopedisi. 8. cilt. İstanbul: Türkiye Diyanet Vakfı Yayınları, 1993, 58. 
Masciotta, Maria Giovanna, Maria Jose Morais, Luis Ramos, Daniel V. Oliveira, Luis Javier Sanchez-Aparicio and D. Gonzalez-Aguilera. "A Digital-based Integrated Methodology for the Preventive Conservation of Cultural Heritage: The Experience of HeritageCare Project." International Journal of Architectural Heritage 13 (2019): 1-20.

Parla, Canan ve Erol Altınsapan. “Atabek Ayaz ve Figürlü Bezemeleriyle Denizli Çardak Han.” Erdem 51 (2008): 195-216.

Pektaş, Kadir. “Çardak Han.” Anadolu Selçuklu Dönemi Kervansarayları. Ankara: Kültür ve Turizm Bakanlığg1 Yayınları, 2007, 161-173.

Riggioo, Mariapaola, Dina D'ayala, Maria Adelaide Parisi ve Chiara Tardini. "Assesment of Heritage Timber Structures: Review of Standards, Guidelines and Procedures." Journal of Cultural Heritage 31 (2018): 220-235.

Romão, Xavier, Paupério Esmeralde ve Nuno Pereira. "A Framework for the Simplified Risk Analysis of Cultural Heritage Assets.” Journal of Cultural Heritage 20 (2016): 696-708.

Şahin, Esra. "Structural Analyses and Assessment of Historical Çardak Caravanserai in Denizli." Yüksek Lisans Tezi, İzmir Yüksek Teknoloji Enstitüsü, 2019.

Tuna, Numan. "Erythrai Arkeolojik Sit Alanında Koruma Sorunları: Erythrai Örneği.” Ege Mimarlı 6/7 (1992): 41-46.

Tükel Yavuz, Ayşıl. "Kervansaraylar.” Anadolu Selçukluları ve Beylikler Dönemi Uygarlığı. 2. cilt. Ankara: Kültür ve Turizm Bakanlığ1 Yayınları, 2006, 439-449.

Erişim 22 Nisan 2020. https://kentrehberi.izmir.bel.tr/ izmirkentrehberi.

Yürütücüler Mine Hamamcıŏlu Turan ve Engin Aktaş; proje ekibi Emre İpekci, Gizem Türkarslan, Serpil Başlılar Altun, Burçin Görür, Canan Durak, N. Mine Tunca, Şeyma Sarıbekiroğlu, Anna Neratzouli, E. Alexandros Maistralis. Destekleyen Kurum: İzmir Yüksek Teknoloji Enstitüsü, Mimari Restorasyon Anabilim Dal1, 2014-2015 Akademik Y1lı Bahar Dönemi, Proje Kodu: RES 502 Mimari Restorasyon Tasarımı II dersi. http://arch.restoration.iyte.edu.tr/izmir-cesme-ildirdaki-aziz-matrone-kilisesinin-restorasyonu-ve-cevresinin-duzenlenmesi-projesi/.

Yürütücü Mine Hamamcıŏlu Turan; danışman: Engin Aktaş; proje ekibi Feyza Durmuşlar, Ayşe Bayram, Canan Nalça, Damla Gül Begüm. Keke, Ebru Özel, Ece Yönetken, Emre Özdemir, Esra Eken, İdil Ece Şener, Merve Ergin, Özüm Birgin, Veli Mustafa Yönder. Destekleyen Kurum: İzmir Yüksek Teknoloji Enstitüsü, Mimari Restorasyon Anabilim Dalı, 2016-2017 Akademik Yılı Bahar Dönemi, Proje Kodu: RES 502 Mimari Restorasyon Tasarımı II dersi. 
